\title{
Cottonseed yield and its quality as affected by mineral fertilizers and plant growth retardants
}

\author{
Zakaria M. Sawan \\ Cotton Research Institute, Agricultural Research Center, Ministry of Agriculture and Land Reclamation, Giza, Egypt; \\ zmsawan@hotmail.com
}

Received 26 December 2013; revised 27 January 2014; accepted 7 February 2014

Copyright (C) 2014 Zakaria M. Sawan. This is an open access article distributed under the Creative Commons Attribution License, which permits unrestricted use, distribution, and reproduction in any medium, provided the original work is properly cited. In accordance of the Creative Commons Attribution License all Copyrights (C) 2014 are reserved for SCIRP and the owner of the intellectual property Zakaria M. Sawan. All Copyright (C) 2014 are guarded by law and by SCIRP as a guardian.

\section{ABSTRACT}

The increase in the population in Egypt makes it imperative to explore promising approaches to increase food supply, including protein and oil, to meet the needs of the Egyptian people. Cotton is the principal crop of Egyptian agriculture, it is grown mainly for its fiber, but cottonseed products are also of economic importance. Cottonseed is presently the main source of edible oil and meal for livestock in Egypt. Economic conditions in modern agriculture demand high crop yields in order to be profitable and consequently meet the high demand for food that comes with population growth. Oil crop production can be improved by development of new high yielding varieties, and the application of appropriate agronomic practices. There is limited information about the most suitable management practice for application of $N, P, K, Z n$, $\mathrm{Ca}$ and PGRs in order to optimize the quantity and quality of oil and protein of cottonseed. In maximizing the quantity and quality of a crop's nutritional value in terms of fatty acids and protein, field experiments were conducted to investigate the effect of nitrogen, phosphorus, potassium, foliar application of zinc and calcium, the use of plant growth retardants (Pix, Cycocel or Alar), on cottonseed, protein, oil yields, and oil properties of Egyptian cotton. From the findings of this study, it seems rational to recommend that application of N, P, K, foliar application of $\mathrm{Zn}$ and $\mathrm{Ca}$, the use of PGRs (Pix, Cycocel or Alar), could bring about better impact on cottonseed yield, seed protein content, oil and protein yields, oil refractive index, unsaponifiable matter, and unsaturated fatty acids in com- parison with the ordinary cultural practices adopted by Egyptian cotton producers.

\section{KEYWORDS}

Calcium; Cottonseed; Nitrogen; Phosphorus; Plant Growth Retardants; Potassium; Zinc

\section{INTRODUCTION}

Plant nutrition, using a balanced fertilization program with both macro and micro-nutrients is becoming necessary in the production of high yield with high quality products especially with the large variation in soil fertility and the crop's need for macro and micro-nutrients. The breeding and production of cotton have traditionally been guided by consideration of fiber quality and yield. However, cottonseed characteristics except for viability and vigor have generally been ignored. Cottonseed oil is an important source of fat. Also, cottonseed meal is classed as a protein supplement in the feed trade and is almost as important as soybean meal [1].

\subsection{Nitrogen}

In cotton culture, nitrogen $(\mathrm{N})$, has a necessity role in production inputs, which controls growth and prevents abscission of squares and bolls, essential for photosynthetic activity [2], and stimulates the mobilization and accumulation of metabolites in newly developed bolls, thus increasing their number and weight. Additionally, with a dynamic crop like cotton, excess $\mathrm{N}$ serves to delay maturity, promote vegetative tendencies, and usually results in lower yields [3]. Therefore, errors made in $\mathrm{N}$ management that can impact the crop can be through either deficiencies or excesses. Ansari and Mahey [4] evaluate the effects of $\mathrm{N}$ level $(0,40,80,120$ and 160 $\mathrm{kg} \cdot \mathrm{ha}^{-1}$ ) on the yield and found that seed yield increased 
with increasing $\mathrm{N}$ level up to $80 \mathrm{~kg} \cdot \mathrm{ha}^{-1}$. Nitrogen is an essential nutrient for the synthesis of fat, which requires both $\mathrm{N}$ and carbon skeletons during the course of seed development [5]. On the other hand, nitrogen plays the most important role in building the protein structure [6]. Another beneficial change in fatty acid composition due to $\mathrm{N}$ nutrition would be an increase in the linoleic and oleic acid contents, and an increase in the percentage of unsaturated fatty acids and a decrease in saturated fatty acids in the seed oil [7].

\subsection{Phosphorus}

Phosphorus (P) is the second most limiting nutrient in cotton production after nitrogen. Its deficiency tends to limit the growth of cotton plants, especially when plants are deprived of $\mathrm{P}$ at early stages than later stages of growth. Further, $\mathrm{P}$ is an essential nutrient and an integral component of several important compounds in plant cells, including the sugar-phosphates involved in respiration, photosynthesis and the phospholipids of plant membranes, the nucleotides used in plant energy metabolism and in molecules of DNA and RNA [8]. Phosphorus deficiency reduces the rate of leaf expansion and photosynthetic rate per unit leaf area [9]. Sasthri et al. [10] found that application of $2 \%$ diammonium phosphate to cotton plants increased seed yield. Improvements in cotton yield resulting from $\mathrm{P}$ application were reported by Stewart et al. [11]; Singh et al. [12]; Ibrahim et al. [13]; Gebaly and El-Gabiery [14].

\subsection{Potassium}

The physiological role of potassium $(\mathrm{K})$ during fruit formation and maturation periods is mainly expressed in carbohydrate metabolism and translocation of metabolites from leaves and other vegetative organs to developing bolls. Potassium increases the photosynthetic rates of crop leaves, $\mathrm{CO}_{2}$ assimilation and facilitating carbon movement [15]. The high concentration of $\mathrm{K}^{+}$is thought to be essential for normal protein synthesis. Potassium deficiency during the reproductive period can limit the accumulation of crop biomass [16], markedly changes the structure of fruit-bearing organs, and decreases yield and quality. Improvements in cotton yield and quality resulting from $\mathrm{K}$ input have been reported by the following authors: Gormus [17] applying $\mathrm{K}$ rates of 66.4, 132.8 and $199.2 \mathrm{~kg} \cdot \mathrm{ha}^{-1} \mathrm{~K}$; Aneela et al. [18] increase $\mathrm{K}$ levels, the effect being highest at $166 \mathrm{~kg} \cdot \mathrm{K} \cdot \mathrm{ha}^{-1}$; Pervez et al. [19] using $\mathrm{K}$ rates of 62.5, 125 and $250 \mathrm{~kg} \cdot \mathrm{ha}^{-1}$; Pettigrew et al. [20] with a K fertilizer rate of 112 $\mathrm{kg} \cdot \mathrm{ha}^{-1}$; Sharma and Sundar [21] with a foliar application of $\mathrm{K}$ at $4.15 \mathrm{~kg} \cdot \mathrm{ha}^{-1}$.

\subsection{Zinc}

Zinc $(\mathrm{Zn})$ is critical for several key enzymes in the plant. Zinc binds tightly to Zn-containing essential metabolites in vegetative tissues, e.g., Zn-activated enzymes such as carbonic anhydrase [22]. Further, $\mathrm{Zn}$ is required in the biosynthesis of tryptophan, a precursor of the auxin-indole-3-acetic acid (IAA), which is the major hormone inhibiting abscission of squares and bolls. Zinc deficiency symptoms include: small leaves, shortened internodes, a stunted appearance, reduced boll set, and small bolls size [23]. Zinc deficiency occurs in cotton on high-pH soils, and where high rates of $\mathrm{P}$ are applied [23]. Rathinavel et al. [24] found that application of $\mathrm{ZnSO}_{4}$, to the soil at $50 \mathrm{~kg} \cdot \mathrm{ha}^{-1}$ increased 100 -seed weight. Li et al. [25] found that when cotton was sprayed with $0.2 \%$ zinc sulfate at the seedling stage, the boll number plant ${ }^{-1}$ increased by $17.3 \%$ and the cotton yield increased by $18.5 \%$ compared with the untreated control.

\subsection{Calcium}

Calcium (Ca) is essential in cell nucleus matrix. It activates enzymes, particularly those that are membranebound [26]. It is thought that $\mathrm{Ca}$ is important in the formation of cell membranes and lipid structures. Ma and Sun [27], suggested that Ca might be involved in light signal transduction chain for phototropism. Calcium deficiency as one of the causes of abscission and suggested this plus the role of $\mathrm{Ca}$ in the middle lamella (Ca pectates) as the possible reason. A likely reason was that Ca deficiency affected translocation of carbohydrates, causing accumulation in the leaves and a decline in stems and roots. It seems probable that young bolls abscised because of starvation. Thus, Ca may inhibit abscission because it is a component of the middle lamella, because it promotes translocation of sugars and auxin, and because it helps prevent senescence. Ochiai [28] notes that $\mathrm{Ca}^{2+}$ can bridge phosphate and carboxylate groups of phospholipids and proteins; that it increases hydrophobicity of membranes; that it generally increases membrane stability and reduces water permeability.

\subsection{Plant Growth Regulators Retardants}

An objective for using plant growth retardants (PGRs) (mepiquat chloride, "Pix", chloromequat chloride, "Cycocel”, and daminozide, "Alar") in cotton is to balance vegetative and reproductive growth as well as to improve yield and its quality [29]. Visual growth-regulating activity of Pix, Cycocel or Alar is similar, being expressed as reduced plant height and width, shortened stem and branch internodes and leaf petioles, influence leaf chlorophyll concentration, structure and $\mathrm{CO}_{2}$ assimilation, and thicker leaves. This indicates that bolls on treated cotton plants have a larger photo synthetically sink for carbohydrates and other metabolites than those on untreated plants. More specific response from using PGRs 
include alteration of carbon partitioning, greater root/ shoot ratios, enhanced photosynthesis, altered nutrient uptake, and altered crop canopy. In this connection, Wang et al. [30] stated that application of the plant growth retardant Pix to the cotton plants at squaring decreased the partitioning of assimilates to the main stem, the branches and their growing points, and increased partitioning to the reproductive organs and roots. Also, they indicated that, from bloom to boll-setting, Pix application was very effective in restricting the vegetative growth of the cotton canopy and in promoting the partitioning of assimilates into reproductive organs. Kumar $e t$ al. [31] evaluated the effects of Chamatkar, 5\% Pix, 500, 750 and $1000 \mathrm{ppm}$, on cotton. These treatments increased the values for photosynthetic rate, transpiration rate, total chlorophyll content, and nitrate reductase activity, number of bolls plant ${ }^{-1}$, boll weight and yield.

Most previous has focused on studying the effect of nitrogen, phosphorus, potassium, foliar application of zinc and calcium, the use of PGRs on cotton yield and fiber quality $[32,33]$. However, there is limited information about the most suitable management practice for application of N, P, K, Zn, Ca and PGRs in order to optimize the quantity and quality of oil and protein of cottonseed [34]. Due to the economic importance of cottonseed (presently the main source of edible oil and meal for livestock) in Egypt, this study was designed to identify the best combination of these production treatments in order to improve cottonseed, protein and oil yields and oil properties of Egyptian cotton (G. barbadense L.) [1,35-37].

\section{METHODS AND MEASUREMENTS}

Field experiments were conducted at the Agricultural Research Center, Ministry of Agriculture in Giza $\left(30^{\circ} \mathrm{N}\right.$, $31^{\circ}: 28^{\prime} \mathrm{E}$ and $19 \mathrm{~m}$ altitude), Egypt using the cotton cultivars "Giza 75" and "Giza 86" (Gossypium barbadense L.) in the two seasons I and II. Seeds were planted on March, and seed cotton was harvest on October [38]. The soil type was a clay loam. Average textural and chemical properties of soil are reported in Table 1 [38]. Range and mean values of the climatic factors recorded during the growing seasons are presented in Table 2 [38]. No rainfall occurred during the two growing seasons. The experiments were arranged as a randomized complete block design. The plot size was $1.95 \times 4 \mathrm{~m}$, including three ridges (beds). Hills were spaced $25 \mathrm{~cm}$ apart on one side of the ridge, and seedlings were thinned to two plants hill $^{-1} 6$ weeks after planting, providing plant density of 123,000 plants $\cdot$ ha $^{-1}$. Total irrigation amount during the growing season (surface irrigation) was about 6000 $\mathrm{m}^{3} \cdot \mathrm{ha}^{-1}$. The first irrigation was applied 3 weeks after sowing, and the second one was 3 weeks later. Thereafter, the plots were irrigated every 2 weeks until the end of the season, thus providing a total of nine irrigations [38].

\subsection{Experiments}

\subsubsection{Effect of N, Zn and PGR's on Cottonseed, Protein, Oil Yields, and Oil Properties}

Materials: A field experiment was conducted, using the cotton cultivar Giza 75. Each experiment included 16 treatments the following combinations: 1) Two N-rtes (107 and 161 of $\mathrm{N} \cdot \mathrm{ha}^{-1}$ ) were applied as ammonium nitrate $(33.5 \% \mathrm{~N})$ in two equal amounts 6 and 8 weeks after sowing; each application (in the form of pinches beside each hill) was followed immediately by irrigation. 2) Three PGR's, 1, 1-dimethylpiperidinium chloride (mepiquat chloride, or Pix), 2-chloroethyltrimethylammonium chloride (chloromequat chloride, or Cycocel), and succinic acid 2, 2-dimethylhydrazide (daminozide, or Alar) were used. Each was foliar-sprayed once at 288 g active ingredient ha ${ }^{-1}, 75$ days after planting (during square initiation and boll setting stage) at solution volume of $960 \mathrm{l} \cdot \mathrm{ha}^{-1}$. Water was used as the control treatment. 3) Two chelated $\mathrm{Zn}$ rates ( 0.0 and $48 \mathrm{~g}$ of $\mathrm{Zn} \mathrm{ha}{ }^{-1}$ ) were foliar-sprayed twice, 80 and 95 days after planting at solution volume of $960 \mathrm{l} \cdot \mathrm{ha}^{-1}$ [35].

\subsubsection{Effect of $P, Z n$ and Ca on Cottonseed, Protein and Oil Yields and Oil Properties}

Materials: A field experiment was conducted on the cotton cultivar Giza 75. Each experiment included 16 treatments, using combinations: 1 ) Two $\mathrm{P}$ rates, 44 (farmer's dose) and $74 \mathrm{~kg}$ of $\mathrm{P}_{2} \mathrm{O}_{5}$ ha $^{-1}$ were applied (as a concentrated band close to the seed ridge) as calcium super-phosphate $\left(15 \% \mathrm{P}_{2} \mathrm{O}_{5}\right)$ before the first irrigation, i.e. 3 weeks after planting (during seedling stage). 2) Two $\mathrm{Zn}$ rates at 0.0 and $40 \mathrm{ppm}$, as chelated form [ethylenediaminetetraacetic acid (EDTA)] each was foliar sprayed twice, 75 and 90 days after planting (during square initiation and boll setting stage) at solution volume of $960 \mathrm{l} \cdot \mathrm{ha}^{-1}$. 3) Four chelated Ca rates at 0.0, 20, 40 and $60 \mathrm{ppm}$ were each foliar sprayed twice, 80 and 95 days after planting, at solution volume of $960 \mathrm{l} \cdot \mathrm{ha}^{-1}$ [36].

\subsubsection{Cottonseed, Protein, Oil Yields, and Oil Properties as Influenced by $\mathrm{K}, \mathrm{P}$ and $\mathrm{Zn}$}

Materials: A field experiment was conducted on the cotton cultivar "Giza 86". Each experiment included 16 treatment combinations of the following: 1) Two K rates ( 0.0 and $47.4 \mathrm{~kg}$ of $\mathrm{K} \mathrm{ha}^{-1}$ ) were applied as $\mathrm{K}$ sulfate $\left(\mathrm{K}_{2} \mathrm{SO}_{4}\right.$, " $\left.48 \% \mathrm{~K}_{2} \mathrm{O}\right)$, eight weeks after sowing (as a concentrated band close to the seed ridge) and the application was followed immediately by irrigation. 2) Two $\mathrm{Zn}$ rates ( 0.0 or $57.6 \mathrm{~g}$ of $\mathrm{Zn} \mathrm{ha}^{-1}$ ) were applied as chelated form and each was foliar sprayed two times (70 and 85 days after planting, during square initiation and boll 
Table 1. Physical and chemical properties of the soil used in I and II seasons.

\begin{tabular}{|c|c|c|}
\hline Season & I & II \\
\hline \multicolumn{3}{|l|}{ Soil texture } \\
\hline Clay (\%) & 43.0 & 46.5 \\
\hline Silt (\%) & 28.4 & 26.4 \\
\hline Fine sand (\%) & 19.3 & 20.7 \\
\hline Coarse sand (\%) & 4.3 & 1.7 \\
\hline Soil texture & Clay & Loam \\
\hline \multicolumn{3}{|l|}{ Chemical analysis } \\
\hline Organic matter (\%) & 1.8 & 1.9 \\
\hline Calcium carbonate (\%) & 3.0 & 2.7 \\
\hline Total soluble salts (\%) & 0.13 & 0.13 \\
\hline $\mathrm{pH}(1: 2.5)$ & 8.1 & 8.1 \\
\hline Total nitrogen (\%) & 0.12 & 0.12 \\
\hline $\begin{array}{l}\left.\text { Available nitrogen (mg } \mathrm{kg}^{-1} \text { soil }\right)^{\mathrm{b}} \\
\qquad\left(1 \% \mathrm{~K}_{2} \mathrm{SO}_{4} \text {, extract }\right)\end{array}$ & 50.0 & 57.5 \\
\hline $\begin{array}{l}\text { Available phosphorus (mg } \cdot \mathrm{kg}^{-1} \text { soil) } \\
\qquad\left(\mathrm{NaHCO}_{3} 0.5 \mathrm{~N} \text {, extract) }\right.\end{array}$ & 15.7 & 14.2 \\
\hline $\begin{array}{l}\left.\text { Available potassium (mg } \cdot \mathrm{kg}^{-1} \text { soil }\right) \\
\qquad\left(\mathrm{NH}_{4} \mathrm{OAC} 1 \mathrm{~N} \text {, extract }\right)\end{array}$ & 370.0 & 385.0 \\
\hline Total Sulphur (mg $\cdot \mathrm{kg}^{-1}$ soil) & 21.3 & 21.2 \\
\hline $\begin{array}{l}\text { Calcium (meq/100 g) } \\
\text { (with Virsen, extract) }\end{array}$ & 0.2 & 0.2 \\
\hline
\end{tabular}

${ }^{a}$ Total nitrogen, i.e. organic $\mathrm{N}+$ inorganic $\mathrm{N} .{ }^{\mathrm{b}}$ Available nitrogen, i.e. $\mathrm{NH}_{4}^{+} \& \mathrm{NO}_{3}^{-}$. The Physical analysis (soil fraction) added to the organic matter, calcium carbonate and total soluble salts to a sum of about $100 \%$ [38].

Table 2. Range and mean values of the weather variables recorded during the growing seasons (April-October).

\begin{tabular}{|c|c|c|c|c|c|c|}
\hline \multirow{2}{*}{ Weather variables } & \multicolumn{2}{|c|}{ Season I } & \multicolumn{2}{|c|}{ Season II } & \multicolumn{2}{|c|}{$\begin{array}{l}\text { Overall date } \\
\text { (Two seasons) }\end{array}$} \\
\hline & Rang & Mean & Range & Mean & Range & Mean \\
\hline Max Temp $\left[{ }^{\circ} \mathrm{C}\right]$ & $20.8-44.0$ & 32.6 & $24.6-43.4$ & 32.7 & $20.8-44.0$ & 32.6 \\
\hline $\operatorname{Min}$ Temp $\left[{ }^{\circ} \mathrm{C}\right]$ & $10.4-24.5$ & 19.4 & $12.0-24.3$ & 19.3 & $10.4-24.5$ & 19.3 \\
\hline Max-Min Temp $\left[{ }^{\circ} \mathrm{C}\right]$ & $4.7-23.6$ & 13.2 & $8.5-26.8$ & 13.4 & $4.7-26.8$ & 13.3 \\
\hline Sunshine $\left[\mathrm{h} \cdot \mathrm{d}^{-1}\right]$ & $0.3-12.9$ & 11.1 & $1.9-13.1$ & 11.2 & $0.3-13.1$ & 11.1 \\
\hline Max Hum [\%] & $48-96$ & 79.5 & $46-94$ & 74.7 & $46-96$ & 77.2 \\
\hline Min Hum [\%] & $6-48$ & 30.1 & $8-50$ & 33.0 & $6-50$ & 31.5 \\
\hline Wind speed $\left[\mathrm{m} \cdot \mathrm{s}^{-1}\right]$ & $0.9-11.1$ & 5.2 & $1.3-11.1$ & 5.0 & $0.9-11.1$ & 5.1 \\
\hline
\end{tabular}

[38].

setting stage). 3) Four phosphorus rates (0.0, 576, 1152 and $1728 \mathrm{~g}$ of $\mathrm{P} \mathrm{ha}{ }^{-1}$ ) were applied as calcium super phosphate $\left(15 \% \mathrm{P}_{2} \mathrm{O}_{5}\right)$ and each was foliar sprayed two times (80 and 95 days after planting). The $\mathrm{Zn}$ and $\mathrm{P}$ were both applied to the leaves with uniform coverage at a solution volume of $960 \mathrm{l} \cdot \mathrm{ha}^{-1}$, using a knapsack sprayer [1].

\subsubsection{Effects N, K and PGR on Oil Content and Quality of Cotton Seed}

Materials: A field experiment was conducted, using the cotton cultivar “Giza 86". The experiment included
16 treatments: 1$)$ soil application of $\mathrm{N}$ (95.2 "the ordinary”, and $142.8 \mathrm{~kg}$ of $\mathrm{N} \mathrm{ha}^{-1}$ as ammonium nitrate), 2) foliar application of $\mathrm{K}\left(0,319,638\right.$ and $957 \mathrm{~g} \cdot \mathrm{K} \cdot \mathrm{ha}^{-1}$ as potassium sulfate) and 3) foliar spray of the PGR (1,1-dimethylpiperidinium chloride (mepiquat chloride "MC" or "Pix") 75 days after planting at 0 or $48 \mathrm{~g}$ a.i. $\mathrm{ha}^{-1}$, and 90 days after planting at 0 or $24 \mathrm{~g} \mathrm{a.i.} \mathrm{ha}^{-1}$ ). The solution volume applied was also $960 \mathrm{~L} \cdot \mathrm{ha}^{-1}$. Nitrogen fertilizer $\left(\mathrm{NH}_{4} \mathrm{NO}_{3}\right.$, “3.5\% $\mathrm{N}$ ") was applied half at 6 and the rest at 8 weeks after planting. The fertilizer was placed beside each hill in the form of pinches and followed immediately by irrigation. Potassium $\left(\mathrm{K}_{2} \mathrm{SO}_{4}\right.$, 
“40\% K”) was applied as foliar spray during square initiation and boll development stage, 70 and 95 days after planting, respectively. The solution volume applied was $960 \mathrm{l} \cdot \mathrm{ha}^{-1}$. The $\mathrm{K}$ and MC were applied to the leaves uniformly using a knapsack sprayer [37].

\subsection{Measurements}

At harvest the seed cotton yield plot $^{-1}$ (handpicking) was determined. Following ginning, the cotton seed yield in $\mathrm{kg} \cdot \mathrm{ha}^{-1}$ as well as 100 -seed weight in $\mathrm{g}$ was determined. A composite seed sample was collected from each treatment for chemical analyses. The following chemical analyses were conducted: 1 ) seed crude protein content according to AOAC standards [39]; 2) seed oil content in which oil was extracted three times with chloroform/methanol (2:1, vol/vol) mixture according to the method outlined by Kates [40]; 3) oil quality traits, i.e., refractive index, acid value, saponification value, unsaponifiable matter, and iodine value were determined according to methods described by AOCS [41]; and 4) identification and determination of oil fatty acids by gasliquid chromatography. The lipid materials were saponified, unsaponifiable matter was removed, and the fatty acids were separated after acidification of the saponifiable materials. The free fatty acids were methylated with diazomethane [42]. The fatty acid methyl esters were analyzed by a Hewlett Packard model 5890 gas chromatograph (Palo Alto, CA) equipped with dual flame-ionization detectors. The separation procedures were similar to those reported by Ashoub et al. [43].

\subsection{Statistical Analysis}

Data obtained for the cottonseed yield and seed weight were statistically analyzed as a factorial experiment in a RCBD following the procedure outlined by Snedecor and Cochran [44] and the least significant difference (LSD) was used to determine the significance of differences between treatment means. As for the chemical properties considered in the study, the t-test computed in accordance with standard deviation was utilized to verify the significance between treatments means [1].

\section{ANALYZED DATA FOR MEASUREMENTS}

\subsection{Experiments}

\subsubsection{Effect of N, Zn and PGR's on Cottonseed, Protein, Oil Yields, and Oil Properties \\ Seed yield ha ${ }^{-1}$, was significantly $(P \leq 0.05)$ increased (8.96\%) by raising $\mathrm{N}$ rate (Table 3 ) [35]. Abdel-Malak et al. [45] stated that cotton yield was higher when $\mathrm{N}$ was applied at a rate of $190 \mathrm{~kg} \cdot \mathrm{ha}^{-1}$ than at the rate of 143 $\mathrm{kg} \cdot \mathrm{ha}^{-1}$. Palomo Gil and Chávez González [32] applied}

$\mathrm{N}$ at a rate ranging from 40 to $200 \mathrm{~kg} \cdot \mathrm{ha}^{-1}$ to cotton plants and found highest yield was associated with high rates of applied N. Similar results were obtained by Sarwar Cheema et al. [33] Saleem et al. [46] when $\mathrm{N}$ was applied at $120 \mathrm{~kg} \cdot \mathrm{ha}^{-1}$; Hamed et al. [47] when $\mathrm{N}$ was applied up to $178 \mathrm{~kg} \cdot \mathrm{ha}^{-1}$. Nitrogen is an important nutrient which control growth and prevents abscission of squares and bolls, essential for photosynthetic activity [2] and stimulate the mobilization and accumulation of metabolites in newly developed bolls and thus their number and weight are increased. All tested PGR (Pix, Cycocel and Alar) significantly increased seed yield ha ${ }^{-1}(7.79 \%$ $12.08 \%)$, compared with the untreated control. The most effective was Pix (12.08\%), followed by Cycocel (10.57\%) [35]. These results may be attributed to the promoting effect of these substances on numerous physiological processes, leading to improvement of all yield components. Pix applications increases $\mathrm{CO}_{2}$ uptake and fixation in cotton plant leaves. In cotton stems, the xylem was expanded with Pix treatment, perhaps increasing the transport ability and accounting for heavier bolls. Alar and Pix also have been associated with increased photosynthesis $[48,49]$ through increased total chlorophyll concentration of plant leaves, increased photosynthesis greatly increased flowering, boll retention and yield. Abdel-Al [50] indicated that cotton yield significantly increased with Pix treatment at a rate $11.90 \mathrm{ml}$ (formulation) $\mathrm{ha}^{-1}$ at the beginning of flowering, and Gebaly and El-Gabiery [14] found that cotton yield significantly increased with Pix application at 1,2 and $3 \mathrm{~cm}^{3} \mathrm{~L}$ (formulation) at pinhead square, start of flowering and peak of flowering stage. Pípolo et al. [51] found that spraying cotton plants at an age of $70 \mathrm{~d}$ after emergence with Cycocel at rates ranging from 25 to $100 \mathrm{~g} \cdot \mathrm{ha}^{-1}$ resulted in yield increases. Sawan et al. [52] stated that application of Cycocel and Alar, at rates ranging from 250 to 700 ppm (105 days after planting) increased cotton seed yield $\mathrm{ha}^{-1}$. Similar results were obtained by Sarwar Cheema et al. [33]. Application of Zn significantly increased seed yield $\mathrm{ha}^{-1}$ (8.44\%), as compared with untreated plants [35]. Zeng [53] stated application of Zn to cotton plants on calcareous soil increased yield by $7.8 \%-25.7 \%$. Similar results were obtained by Ibrahim et al. [13]. Zinc is required in the synthesis of tryptophan, which is a precursor of IAA synthesis which is the hormone that inhibits abscission of squares and bolls. Also, this nutrient has favorable effect on the photosynthetic activity of leaves and plant metabolism [25], which might account for higher accumulation of metabolites in reproductive organs (bolls).

Seed index significantly increased with increasing $\mathrm{N}$ rate (Table 3) [35]. This may be partially due to enhanced photosynthetic activity [2]. Similar findings were obtained by Palomo Gil and Chávez González [32]; 
Table 3. Effect of $\mathrm{N}$ rate and foliar application of plant growth retardants and $\mathrm{Zn}$ on cottonseed yield, seed index, seed oil, seed protein, oil and protein yields.

\begin{tabular}{|c|c|c|c|c|c|c|c|}
\hline Treatments & & $\begin{array}{l}\text { Cottonseed yield } \\
\left(\mathrm{kg} \cdot \mathrm{ha}^{-1}\right)^{\mathrm{a}}\end{array}$ & $\begin{array}{l}\text { Seed index } \\
(\mathrm{g})^{\mathrm{a}}\end{array}$ & $\begin{array}{c}\text { Seed Oil } \\
(\%)^{\mathrm{b}}\end{array}$ & $\begin{array}{l}\text { Oil yield } \\
\left(\mathrm{kg} \cdot \mathrm{ha}^{-1}\right)^{\mathrm{b}}\end{array}$ & $\begin{array}{l}\text { Seed protein } \\
(\%)^{\mathrm{b}}\end{array}$ & $\begin{array}{l}\text { Protein yield } \\
\left(\mathrm{kg} \cdot \mathrm{ha}^{-1}\right)^{\mathrm{b}}\end{array}$ \\
\hline \multicolumn{8}{|l|}{ N-rate $\left(\mathrm{kg} \cdot \mathrm{ha}^{-1}\right)$} \\
\hline \multirow[t]{2}{*}{ Control } & 107 & 1907.7 & 10.29 & 19.92 & 380.1 & 21.96 & 418.8 \\
\hline & 161 & 2078.7 & 10.44 & 19.87 & 413.0 & 22.51 & 468.4 \\
\hline L.S.D. $0.05^{\mathrm{c}}$ & & 67.8 & 0.06 & - & - & - & - \\
\hline S.E. ${ }^{d}$ & & - & - & 0.02 & 16.4 & 0.27 & 24.8 \\
\hline \multicolumn{8}{|c|}{ Plant growth retardants (ppm) } \\
\hline Control & 0 & 1852.2 & 10.24 & 19.86 & 368.0 & 22.08 & 409.1 \\
\hline Pix & 300 & 2076.0 & 10.44 & 19.88 & 413.2 & 22.35 & 465.0 \\
\hline Cycocel & 300 & 2048.0 & 10.41 & 19.94 & 407.8 & 22.24 & 455.8 \\
\hline Alar & 300 & 1996.5 & 10.36 & 19.90 & 397.3 & 22.26 & 444.5 \\
\hline L.S.D. $0.05^{\mathrm{c}}$ & & 96.0 & 0.08 & - & - & - & - \\
\hline S.E. ${ }^{\text {d }}$ & & - & - & 0.01 & 10.1 & 0.05 & 12.2 \\
\hline \multicolumn{8}{|l|}{$\mathrm{Zn}$ rate (ppm) } \\
\hline \multirow[t]{2}{*}{ Control } & 0 & 1912.4 & 10.30 & 19.82 & 379.2 & 22.10 & 422.8 \\
\hline & 50 & 2073.9 & 10.42 & 19.97 & 413.9 & 22.37 & 464.4 \\
\hline L.S.D. $0.05^{\mathrm{c}}$ & & 67.8 & 0.06 & - & - & - & - \\
\hline S.E. ${ }^{d}$ & & - & - & 0.07 & 17.3 & 0.13 & 20.8 \\
\hline
\end{tabular}

${ }^{\mathrm{a}}$ Combined statistical analysis from the two seasons. ${ }^{\mathrm{b}}$ Mean data from a four replicate composite for the two seasons. ${ }^{\mathrm{d}}$ L.S.D. $=$ Least significant differences, ${ }^{\mathrm{c}}$ S.E. = standard error. [35].

Hamed et al. [47]. Application of all PGR significantly increased seed index as compared to untreated control; Pix gave the highest seed index, followed by Cycocel [35]. These agree with previous works of Sawan et al. [52], by applying Cycocel and Alar; Carvalho et al. [54] by applying Pix and Cycocel; Abdel-Al [50], by applying Pix. Zinc significantly increased seed index compared with the untreated control [35]. In this connection Ibrahim et al. [13] noted that seed weight increased due to the application of Zn.

Seed oil content was unchanged with increased as $\mathrm{N}$-rate. Oil yield ha ${ }^{-1}$ significantly (32.9 $\mathrm{kg} \cdot \mathrm{ha}^{-1}$ ), which is attributed to the increase in seed yield (Table 3) [35]. Pandrangi et al. [55] applied $\mathrm{N}$ at a rate of 25 or 50 $\mathrm{kg} \cdot \mathrm{ha}^{-1}$ to cotton plants and found that the percentage of seed oil content decreased but oil yield increased with increasing $\mathrm{N}$ rate. Application of all growth retardants resulted in an insignificant increase in seed oil content above the control and also significantly increased the oil yield ha ${ }^{-1}$ over the control (29.3 - $45.2 \mathrm{~kg}$ oil ha $\left.^{-1}\right)$, with the clearest effect from Pix $\left(45.2 \mathrm{~kg} \cdot \mathrm{ha}^{-1}\right)$, followed by Cycocel (39.8 $\left.\mathrm{kg} \cdot \mathrm{ha}^{-1}\right)$ [35]. Sawan et al. [56] indicated that a slight increase in cottonseed oil content was detected with Pix application at rate ranging $10-100$ ppm. Pix was sprayed once (90 D) or twice (90 and 110 days after planting). Oil yield also increased due to Pix application compared with the control. Similar results were obtained by Gebaly and El-Gabiery [14]. Sawan et al. [52] observed that application of Cycocel and Alar (250 $750 \mathrm{ppm}, 105$ days after planting) increased oil yield $\mathrm{ha}^{-1}$. Application of $\mathrm{Zn}$ resulted in an insignificant increase in seed oil content over that of the control. The seed oil yield was also increased $\left(34.7 \mathrm{~kg}_{\text {oil ha }}{ }^{-1}\right)$ compared with the untreated control [35]. These results could be attributed to the increase of total photoassimilates (e.g. lipids) and the translocated assimilates to the sink as a result of applying Zn nutrient. Sawan et al. [57] found that oil yield increased by the application of $\mathrm{Zn}$ to cotton plants at a rate of $12 \mathrm{~g} \mathrm{Zn} \mathrm{ha}^{-1}$. Zinc was sprayed three times, i.e., 70, 85, and $100 \mathrm{~d}$ after sowing. Prabhuraj et al. [58] found that applying $\mathrm{Zn}$ at $5 \mathrm{ppm}$ rate increased seed and oil yields of sunflower. Similar results were obtained by Ibrahim et al. [13] on cotton; Bybordi and Mamedov [59] on canola.

High $\mathrm{N}$ rate significantly increased the seed protein content and yield ha ${ }^{-1}$ (49.6 kg protein ha ${ }^{-1}$ ) (Table 3) [35]. According to Sugiyama et al. [60], soluble proteins are increased with better $\mathrm{N}$ supply and favorable growth condition. These results suggest that the high $\mathrm{N}$-rate increases the amino acids synthesis in the leaves, and this stimulates the accumulation of protein in the seed rather than oil content. Patil et al. [5] found that $\mathrm{N}$ application $\left(50 \mathrm{~kg} \cdot \mathrm{N} \cdot \mathrm{ha}^{-1}\right)$ increased the seed protein content. Seed protein content and yield ha ${ }^{-1}$ were increased insignifi- 
cantly in plants in plants treated with the three growth retardants (35.4 - $55.9 \mathrm{~kg}$ protein $\mathrm{ha}^{-1}$ ) compared with the untreated control. Highest protein content was produced by Pix application, followed by Alar, while the highest seed protein yield was obtained with Pix (55.9 $\left.\mathrm{kg} \cdot \mathrm{ha}^{-1}\right)$, and followed by Cycocel $\left(46.7 \mathrm{~kg} \cdot \mathrm{ha}^{-1}\right)$ [35]. Hedin et al. [61] found that Cycocel increased protein content by $17 \%-50 \%$ in leaves and squares harvested 4 wk after the first application. Kar et al. [62] in safflower showed that Cycocel and Alar maintained the level of chlorophyll, protein, and RNA contents. Also, the increase in seed protein content may be caused by the role of Pix in protein synthesis, encouraging the conversion of amino acids into protein [63]. Sawan et al. [56]; Gebaly and El-Gabiery [14] stated that cottonseed protein content and yield ha ${ }^{-1}$ increased due to the application of Pix. Kler et al. [64] found that when cotton was sprayed using Cycocel rates of 40,60 , or $80 \mathrm{ppm}$ at the age 63 days after planting, seed protein content increased. Sawan et al. [52] stated that application of Cycocel or Alar increased seed protein content and protein yield $\mathrm{ha}^{-1}$. Application of zinc increased insignificantly the seed protein content and significantly increased protein yield $\mathrm{ha}^{-1}$ (41.6 kg protein ha ${ }^{-1}$ ) over the untreated control [35]. In these circumstances Ibrahim et al. [13] found that application of $\mathrm{Zn}$ to cotton plants increased seed protein content and protein yield $\mathrm{ha}^{-1}$.

The seed oil refractive index and unsaponifiable matter tended to increase insignificantly, while the oil acid value and saponification value tended to decrease by raising N-rate (Table 4) [35]. The increase in unsaponi- fiable matter is beneficial as it increases the oil stability. Sawan et al. [57] applied $\mathrm{N}$ to cotton plants at rates of 108 and $216 \mathrm{~kg} \cdot \mathrm{ha}^{-1}$ and found that oil unsaponifiable matter tended to increase, while saponification value tended to decrease by raising $\mathrm{N}$-rate. Application of all PGR significantly increased the oil refractive index. However, unsaponifiable matter was insignificantly increased, whereas acid value and saponification value tended to decrease insignificantly as compared with the untreated control [35]. Applied Cycocel gave the highest refractive index and the lowest acid value, while Pix gave the highest unsaponifiable matter. Also, applied Alar gave the lowest saponification value. Sawan et al. [32] stated that application of Cycocel and Alar to cotton plants increased oil refractive index and unsaponifiable matter and decreased oil acid value and saponification value. Osman and Abu-Lila [65] found a negligible variation in refractive index of flax oil when the plants were treated with Cycocel at the application rates of 25 - 100 ppm twice; the first one $20 \mathrm{~d}$ after sowing and the second spray 2 months later. The oil refractive index and unsaponifiable matter tended to increase insignificantly, while acid value and saponification value decreased insignificantly by applied zinc compared with control [35]. Sawan et al. [57] found that application of $\mathrm{Zn}$ to cotton plants exhibited negligible effect upon oil-quality characters, i.e., refractive index, oil acid value, unsaponifiable matter, and saponification value.

The oil saturated fatty acids (capric, myristic, palmitic and stearic) decreased insignificantly, while lauric acid increased insignificantly in response to raising the $\mathrm{N}$-rate

Table 4. Effect of $\mathrm{N}$ rate and foliar application of plant growth retardants and Zn on seed oil properties ${ }^{\mathrm{a}}$.

\begin{tabular}{|c|c|c|c|c|c|}
\hline \multicolumn{2}{|c|}{ Treatments } & \multirow[t]{2}{*}{ Refractive index } & \multirow[t]{2}{*}{ Acid value } & \multirow[t]{2}{*}{$\begin{array}{l}\text { Saponification } \\
\text { value }\end{array}$} & \multirow{2}{*}{$\begin{array}{c}\text { Unsaponifiable matter } \\
(\%)\end{array}$} \\
\hline N-rate $(\mathrm{k}$ & & & & & \\
\hline Control & 107 & 1.4733 & 0.1336 & 193.7 & 0.3700 \\
\hline & 161 & 1.4734 & 0.1310 & 191.6 & 0.3738 \\
\hline S.E. ${ }^{b}$ & & 0.0001 & 0.0013 & 1.0 & 0.0019 \\
\hline \multicolumn{6}{|c|}{ Plant growth retardant (ppm) } \\
\hline Control & 0 & 1.4729 & 0.1338 & 193.4 & 0.3675 \\
\hline Pix & 300 & 1.4734 & 0.1327 & 192.9 & 0.3750 \\
\hline Cycocel & 300 & 1.4738 & 0.1312 & 193.1 & 0.3725 \\
\hline Alar & 300 & 1.4735 & 0.1317 & 191.2 & 0.3725 \\
\hline S.E. ${ }^{b}$ & & 0.0002 & 0.0005 & 0.5 & 0.0015 \\
\hline \multicolumn{6}{|c|}{ Zn rate (ppm) } \\
\hline \multirow[t]{2}{*}{ Control } & 0 & 1.4732 & 0.1325 & 193.8 & 0.3688 \\
\hline & 50 & 1.4735 & 0.1322 & 191.6 & 0.3750 \\
\hline S.E $\mathrm{E}^{\mathrm{b}}$ & & 0.0001 & 0.0001 & 1.1 & 0.0031 \\
\hline
\end{tabular}

${ }^{\mathrm{a}}$ Mean data from a four replicate composite for the two seasons. ${ }^{\mathrm{b}}$ S.E. = standard error [35]. 
(Table 5) [35]. Palmitic acid was the dominant saturated fatty acid. Low content of saturated fatty acids is desirable for edible uses. Application of the three PGR's resulted in a decrease in the total saturated fatty acids compared with the untreated control. The decrease was significant with the Cycocel and Alar treatments. Cycocel gave the lowest total saturated fatty acids in oil contents, followed by Alar and also tended to increase insignificantly the saturated fatty acid capric acid compared with the untreated control. Applied Pix gave the highest capric and the lowest stearic acid content, while applied Cycocel gave the lowest lauric acid content. Alar application tended to give the lowest myristic and palmitic acids contents compared with control. Application of $\mathrm{Zn}$ resulted in a significant decrease in the total saturated fatty acids (capric, palmitic and stearic) while it resulted in an increase in the lauric and myristic saturated fatty acids, compared with untreated plants [35].

The total unsaturated fatty acids (oleic and linoleic) and the ratio between total unsaturated fatty acids and total saturated fatty acids (TU/TS) increased insignificantly (3.53 and 15.93\%, respectively) by raising N-rate (Table 6) [35]. Linoleic acid was the most abundant of the unsaturated fatty acids. Kheir et al. [7] found that the higher N-rate increased the percentage of unsaturated fatty acids and decreased saturated fatty acids of flax oil. All PGR's increased the total unsaturated fatty acids and TU/TS ratio, compared with the control. The increase was significant by the application of Cycocel and Alar. Applied Cycocel gave the highest linoleic acid content, total unsaturated fatty acids (10.64\%), and TU/TS ratio (51.0\%), and followed by Alar (10.02 and 47.01\%, respectively) [35]. The increase in TU/TS as a result of the application of the three PGR may be attributed to their encouraging effects on enzymes that catalyzed the biosynthesis of the unsaturated fatty acids. Spraying plants with $\mathrm{Zn}$ significantly increased the total unsaturated fatty acids (7.4\%) and TU/TS ratio (35.04\%), compared with untreated control [35]. Sawan et al. [56] reported that applying Pix to cotton plants caused a general decrease in oil saturated fatty acids, associated with an increase in oil unsaturated fatty acids. Sawan et al. [52] stated that application of Cycocel and Alar to cotton increased oil unsaturated fatty acids. Osman and Abu-Lila [65] when applied Cycocel at rates of 25 - 100 ppm to flax plants found that generally the higher concentrations (50 and $100 \mathrm{ppm}$ ) caused in the total oil saturated fatty acids, while they increased the unsaturated fatty acids.

\subsubsection{Effect of $P, \mathrm{Zn}$ and $\mathrm{Ca}$ on Cottonseed, Protein and Oil Yields and Oil Properties}

Seed yield ha ${ }^{-1}$ was significantly increased (11.24\%) when phosphorus was applied at the highest rate (Table 7) [36]. Phosphorus as a constituent of cell nuclei is essential for cell division and development of meristematic tissue, and hence it should have a stimulating effect on the plants, increasing the number of flowers and bolls per plant. Further, $\mathrm{P}$ has a well known impact in photosynthesis as well as synthesis of nucleic acids, proteins, lipids and other essential compounds [66], all of which are major factors affecting boll weight and consequently cottonseed. These results are confirmed by those of Abdel-Malak et al. [45]; Ibrahim et al. [13]; Saleem et al. [67]; Gebaly and El-Gabiery [60]. Application of Zn significantly increased cottonseed yield ha ${ }^{-1}$ (8.61\%), as compared with the untreated control [36]. This may be

Table 5. Effect of $\mathrm{N}$ rate and foliar application of plant growth retardants and $\mathrm{Zn}$ on the relative percentage of saturated fatty acids ${ }^{\mathrm{a}}$.

\begin{tabular}{|c|c|c|c|c|c|c|c|}
\hline \multirow{2}{*}{\multicolumn{2}{|c|}{ Treatments }} & \multicolumn{6}{|c|}{ Relative \% of saturated fatty acids } \\
\hline & & Capric & Lauric & Myristic & Palmitic & Stearic & Total \\
\hline \multicolumn{8}{|c|}{ N-rate $\left(\mathrm{kg} \cdot \mathrm{ha}^{-1}\right)$} \\
\hline \multirow[t]{2}{*}{ Control } & 107 & 0.5887 & 0.4375 & 0.7700 & 20.72 & 2.767 & 25.283 \\
\hline & 161 & 0.3212 & 0.8212 & 0.6812 & 18.67 & 2.152 & 22.646 \\
\hline S.E $E^{b}$ & & 0.1337 & 0.1918 & 0.0444 & 1.02 & 0.307 & 1.319 \\
\hline \multicolumn{8}{|c|}{ Plant growth retardants (ppm) } \\
\hline Control & 0 & 0.3350 & 1.2325 & 1.4050 & 23.06 & 2.427 & 28.459 \\
\hline Pix & 300 & 0.7500 & 0.7125 & 0.9225 & 20.88 & 1.982 & 25.247 \\
\hline Cycocel & 300 & 0.3600 & 0.2600 & 0.3200 & 17.59 & 2.327 & 20.857 \\
\hline Alar & 300 & 0.3750 & 0.3125 & 0.2550 & 17.25 & 3.102 & 21.294 \\
\hline S.E $E^{b}$ & & 0.0986 & 0.2250 & 0.2717 & 1.38 & 0.234 & 1.794 \\
\hline \multicolumn{8}{|c|}{ Ca rate (ppm) } \\
\hline \multirow[t]{2}{*}{ Control } & 0 & 0.6325 & 0.5825 & 0.5825 & 22.41 & 2.472 & 26.679 \\
\hline & 50 & 0.2775 & 0.6762 & 0.8687 & 16.98 & 2.447 & 21.249 \\
\hline S.E $E^{b}$ & & 0.1775 & 0.0468 & 0.1431 & 2.71 & 0.012 & 2.715 \\
\hline
\end{tabular}

${ }^{\mathrm{a}}$ Mean data from a four replicate composite for the two seasons. ${ }^{\mathrm{b}}$ S.E. = standard error [35]. 
Table 6. Effect of $\mathrm{N}$ rate and foliar application of plant growth retardants and $\mathrm{Zn}$ on the relative percentage of unsaturated fatty acids $^{\mathrm{a}}$.

\begin{tabular}{|c|c|c|c|c|c|}
\hline \multirow{2}{*}{\multicolumn{2}{|c|}{ Treatments }} & \multicolumn{3}{|c|}{ Relative \% of unsaturated fatty acids } & \multirow{2}{*}{$\begin{array}{c}\mathrm{TU}^{\mathrm{T}} \mathrm{TS}^{\mathrm{b}} \\
\text { ratio }\end{array}$} \\
\hline & & Oleic & Linoleic & Total & \\
\hline \multicolumn{6}{|c|}{$\mathrm{N}$ rate $\left(\mathrm{kg} \cdot \mathrm{ha}^{-1}\right)$} \\
\hline \multirow[t]{2}{*}{ Control } & 107 & 21.67 & 53.04 & 74.71 & 2.95 \\
\hline & 161 & 22.57 & 54.78 & 77.35 & 3.42 \\
\hline S.E. ${ }^{c}$ & & 0.45 & 0.87 & 1.32 & 0.23 \\
\hline \multicolumn{6}{|c|}{ Plant growth retardants (ppm) } \\
\hline Control & 0 & 20.67 & 50.86 & 71.53 & 2.51 \\
\hline Pix & 300 & 21.20 & 53.55 & 74.75 & 2.96 \\
\hline Cycocel & 300 & 23.07 & 56.07 & 79.14 & 3.79 \\
\hline Alar & 300 & 23.54 & 55.16 & 78.70 & 3.69 \\
\hline S.E. ${ }^{c}$ & & 0.69 & 1.14 & 1.79 & 0.30 \\
\hline \multicolumn{6}{|c|}{ Zn rate (ppm) } \\
\hline \multirow[t]{2}{*}{ Control } & 0 & 21.46 & 51.86 & 73.32 & 2.74 \\
\hline & 50 & 22.79 & 55.96 & 78.75 & 3.70 \\
\hline S.E $E^{c}$ & & 0.66 & 2.05 & 2.71 & 0.48 \\
\hline
\end{tabular}

${ }^{\mathrm{a}}$ Mean data from a four replicate composite for the two seasons. ${ }^{\mathrm{b}} \mathrm{TU} / \mathrm{TS}$ ratio = (total unsaturated fatty acids)/(total saturated fatty acids). ${ }^{\mathrm{c}} \mathrm{S}$.E. $=$ standard error [35].

Table 7. Effect of $\mathrm{P}$ rate and foliar application of $\mathrm{Zn}$ and $\mathrm{Ca}$ on cottonseed yield, seed index, seed oil, seed protein, oil and protein yields.

\begin{tabular}{|c|c|c|c|c|c|c|c|}
\hline Treatments & & $\begin{array}{c}\text { Cottonseed yield } \\
\left(\mathrm{kg} \cdot \mathrm{ha}^{-1}\right)^{\mathrm{a}}\end{array}$ & $\begin{array}{l}\text { Seed index } \\
(\mathrm{g})^{\mathrm{a}}\end{array}$ & $\begin{array}{c}\text { Seed Oil } \\
(\%)^{\mathrm{b}}\end{array}$ & $\begin{array}{l}\text { Oil Yield } \\
\left(\mathrm{kg} \cdot \mathrm{ha}^{-1}\right)^{\mathrm{b}}\end{array}$ & $\begin{array}{l}\text { Seed protein } \\
(\%)^{\mathrm{b}}\end{array}$ & $\begin{array}{l}\text { Protein yield } \\
\left(\mathrm{kg} \cdot \mathrm{ha}^{-1}\right)^{\mathrm{b}}\end{array}$ \\
\hline \multicolumn{8}{|l|}{$\mathrm{P}_{2} \mathrm{O}_{5}$ rate $\left(\mathrm{kg} \cdot \mathrm{ha}^{-1}\right)$} \\
\hline \multirow[t]{2}{*}{ Control } & 44 & 1837.1 & 10.19 & 19.67 & 361.6 & 22.35 & 410.6 \\
\hline & 74 & 2043.5 & 10.40 & 19.86 & 406.0 & 22.38 & 457.5 \\
\hline L.S.D. $0.05^{c}$ & & 41.2 & 0.05 & - & - & - & - \\
\hline S.E. ${ }^{d}$ & & - & - & 0.09 & 22.2 & 0.01 & 23.4 \\
\hline \multicolumn{8}{|l|}{ Zn rate (ppm) } \\
\hline \multirow[t]{2}{*}{ Control } & 0 & 1860.2 & 10.24 & 19.59 & 364.5 & 22.22 & 413.4 \\
\hline & 40 & 2020.4 & 10.36 & 19.94 & 403.0 & 22.51 & 454.7 \\
\hline L.S.D. $0.05^{\mathrm{c}}$ & & 41.2 & 0.05 & - & - & - & - \\
\hline S.E. ${ }^{d}$ & & - & - & 0.17 & 19.2 & 0.14 & 20.6 \\
\hline \multicolumn{8}{|l|}{ Ca rate (ppm) } \\
\hline \multirow[t]{4}{*}{ Control } & 0 & 1807.1 & 10.16 & 19.74 & 356.8 & 22.43 & 405.3 \\
\hline & 20 & 1934.6 & 10.31 & 19.76 & 382.7 & 22.36 & 432.9 \\
\hline & 40 & 1992.7 & 10.34 & 19.75 & 394.2 & 22.34 & 445.5 \\
\hline & 60 & 2026.8 & 10.37 & 19.82 & 401.3 & 22.34 & 452.4 \\
\hline L.S.D. $0.05^{\mathrm{c}}$ & & 58.2 & 0.07 & - & - & - & - \\
\hline S.E. ${ }^{d}$ & & - & - & 0.01 & 9.7 & 0.02 & 10.3 \\
\hline
\end{tabular}

${ }^{\mathrm{a}}$ Combined statistical analysis from the two seasons. ${ }^{\mathrm{b}}$ Mean data from a four replicate composite for the two seasons. ${ }^{\mathrm{C}}$ L.S.D. $=$ Least significant differences. ${ }^{\mathrm{d}}$ S.E. = standard error [36].

due to its favorable effect on photosynthetic activity, which improves mobilization of photosynthates and directly influences of boll weight [68]. Also, $\mathrm{Zn}$ enhances the activity of tryptophan synthesis, which is involved in the synthesis of the growth control compound IAA, the major hormone that inhibits abscission of squares and bolls. The application of $\mathrm{Zn}$ increased the number of retained bolls plant ${ }^{-1}$. Similar results were obtained by Zeng [53]; Ibrahim et al. [13] on cotton; Bybordi and Mamedov [59] on canola. Calcium application also significantly increased seed yield $(7.06 \%-12.16 \%)$, as yields resulting from the three concentrations applied exceeded the control. In general, it can be stated that the highest Ca concentration (60 ppm) was more effective 
than the other two concentrations (20 or $40 \mathrm{ppm}$ ) [36]. The role of $\mathrm{Ca}$ in increasing seed yield can possibly be ascribed to its involvement in the process of photosynthesis and the translocation of carbohydrates to young bolls. Calcium deficiency depressed the rate of photosynthesis (rate of $\mathrm{CO}_{2}$ fixation). Guinn [66] stated that Ca deficiency would cause carbohydrates to accumulate in leaves and not in young bolls. The results obtained agree with those reported by Shui and Meng [69]; Wright et al. [70].

The application of $\mathrm{P}$ at the rate of $74 \mathrm{~kg} \mathrm{P}_{2} \mathrm{O}_{5} \mathrm{ha}^{-1}$ significantly increased seed index (weight of 100 seed in g) relative to the application at $44 \mathrm{~kg} \mathrm{P}_{2} \mathrm{O}_{5} \mathrm{ha}^{-1}$ (Table 7) [36]. A possible explanation for increased seed weight due to the application of $\mathrm{P}$ at the higher rate is that this nutrient activated biological reactions in the cotton plants, particularly $\mathrm{CO}_{2}$ fixation and the synthesis of sugar, amino acids, protein, lipids and other organic compounds. It also increased the translocation of assimilates from photosynthetic organs to the sink [71]. Similar results were obtained by El-Debaby et al. [72]. Application of Zn significantly increased seed index, compared to the control [36]. This may be due to its favorable effect on photosynthetic activity. Zinc improves mobilization of photosynthates and directly influences boll weight that coincide directly with increased seed index. These results are confirmed by those obtained by Ibrahim et al. [13]. Calcium applied at all rates significantly increased seed index over the control [36]. The highest rate of Ca (60 $\mathrm{ppm}$ ) showed the highest numerical value of seed index. Similar results were obtained by Ibrahim et al. [13].

Raising the phosphorus rate increased seed oil content and oil yield $\mathrm{ha}^{-1}$ (Table 7) [36]. This may be attributed to the fact that $\mathrm{P}$ is required for production of high quality seed, since it occurs in coenzymes involved in energy transfer reactions. Energy is tapped in photosynthesis in the form of adenosine triphosphate (ATP) and nicotinamide adenine dinucleotide phosphate (NADP). This energy is then used in photosynthetic fixation of $\mathrm{CO}_{2}$ and in the synthesis of lipids and other essential organic compounds [8]. These results agree with those obtained by Pandrangi et al. [55]; Gebaly and El-Gabiery [14]. Spraying plants with zinc resulted in an increase of seed oil content and oil yield $\mathrm{ha}^{-1}$ when compared with the untreated control [36]. This could be attributed to the increase of total photo assimilates (e.g. lipids) and the translocated assimilates to the sink as a result of applying zinc. Similar results were reached by Ibrahim et al. [13]. Application of $\mathrm{Ca}$ at all concentration tended to increase the seed oil content and oil yield ha ${ }^{-1}$ over the control; the best result was from the highest Ca concentration (60 ppm) [36]. These results agreed with those obtained by Bora [73] on rape; Ibrahim et al. [13] on cotton; Bybordi and Mamedov [59] on canola. A possible role of Ca as an activator of the enzyme phospholipase in cabbage leaves has been investigated by Davidson and Long [74].

Applying $\mathrm{P}$ at the higher rate slightly increased seed protein content (Table 7) [36]. It also increased the protein yield $\mathrm{ha}^{-1}$, resulting from an improvement in both seed yield and seed protein content. Phosphorus is a component of nucleic acids which are necessary for protein synthesis [66]. Similar results were obtained by Ibrahim et al. [13]; Gebaly and El-Gabiery [14] in cotton. The application of $\mathrm{Zn}$ increased the seed protein content and protein yield ha ${ }^{-1}$, compared with the untreated control [36]. Shchitaeva [75] found that the synthesis of metabolically active amino acids depends on Zn, which increases the synthesis of asparagine and tryptophan. These results agree with studies reported by Ibrahim et al. [13]. Calcium applied at all rates tended to decrease the seed protein content slightly, but protein yield $\mathrm{ha}^{-1}$ increased compared with the untreated control, which is attributed to the increase in cottonseed yield. The best protein yield was obtained at the highest $\mathrm{Ca}$ concentration (60 ppm) [36].

The oil refractive index and unsaponifiable matter tended to increase, while the acid value and saponification value tended to decrease as phosphorus rate was raised (Table 8) [36]. The increase in unsaponifiable matter is known to be beneficial, as it increases oil stability. Spraying plants with Zn resulted in a slight increase in the oil refractive index and unsaponifiable matter and a slight decrease in acid value and saponification value, compared with the untreated control [36]. Similar results were obtained by Sawan et al. [57] concerning the effect of applied $\mathrm{Zn}$ on oil refractive index, unsaponifiable matter and saponification value. Application of $\mathrm{Ca}$ at any concentration tended to decrease the oil acid value and saponification value and to increase the unsaponifiable matter, especially as the applied Ca concentration increased, compared with the untreated control [36]. This became especially apparent as the applied calcium concentration was increased. The effect of Ca concentrations on oil refractive index was very limited and without a defined trend. These results are in agreement with those reported by Sawan et al. [57] concerning the effect of applied Ca on oil refractive index, saponification value and unsaponifiable matter. The studied oil quality characters seemed to be genetically controlled.

The high rate of applied $\mathrm{P}$ decreased the oil saturated fatty acids capric, myristic, palmitic and stearic, while it increased lauric acid (Table 9). The total saturated fatty acids also decreased. Palmitic acid was the predominant saturated fatty acid. Low content of saturated fatty acids is desirable for edible uses [36]. The application of $\mathrm{Zn}$ decreased the abundant saturated fatty acids palmitic and myristic, while it increased capric, lauric and stearic saturated fatty acids, compared to the control. The total 
Table 8. Effect of P rate and foliar application of $\mathrm{Zn}$ and Ca on seed oil properties ${ }^{\mathrm{a}}$.

\begin{tabular}{|c|c|c|c|c|c|}
\hline \multicolumn{2}{|c|}{ Treatments } & Refractive index & Acid value & Saponification value & Unsaponifiable matter (\%) \\
\hline \multicolumn{6}{|c|}{$\mathrm{P}_{2} \mathrm{O}_{5}$ rate $\left(\mathrm{kg} \cdot \mathrm{ha}^{-1}\right)$} \\
\hline \multirow[t]{2}{*}{ Control } & 44 & 1.4688 & 0.1332 & 192.9 & 0.3575 \\
\hline & 74 & 1.4691 & 0.1327 & 191.5 & 0.3662 \\
\hline S.E $E^{b}$ & & 0.0001 & 0.0002 & 0.7 & 0.0043 \\
\hline \multicolumn{6}{|c|}{ Zn rate (ppm) } \\
\hline \multirow[t]{2}{*}{ Control } & 0 & 1.4687 & 0.1331 & 192.4 & 0.3538 \\
\hline & 40 & 1.4692 & 0.1328 & 192.0 & 0.3700 \\
\hline S.E $E^{b}$ & & 0.0002 & 0.0001 & 0.2 & 0.0081 \\
\hline \multicolumn{6}{|c|}{ Ca rate (ppm) } \\
\hline \multirow[t]{4}{*}{ Control } & 0 & 1.4689 & 1.1340 & 194.9 & 0.3550 \\
\hline & 20 & 1.4688 & 0.1330 & 191.4 & 0.3575 \\
\hline & 40 & 1.4688 & 0.1324 & 191.3 & 0.3650 \\
\hline & 60 & 1.4692 & 0.1324 & 191.2 & 0.3700 \\
\hline S.E $E^{b}$ & & 0.0001 & 0.0003 & 0.9 & 0.0034 \\
\hline
\end{tabular}

${ }^{\mathrm{a}}$ Mean data from a four replicate composite for the two seasons. ${ }^{\mathrm{b}} \mathrm{S} . \mathrm{E} . \mathrm{=}$ standard error [36].

Table 9. Effect of $\mathrm{P}$ rate and foliar application of $\mathrm{Zn}$ and $\mathrm{Ca}$ on the relative percentage of saturated fatty acids ${ }^{\mathrm{a}}$.

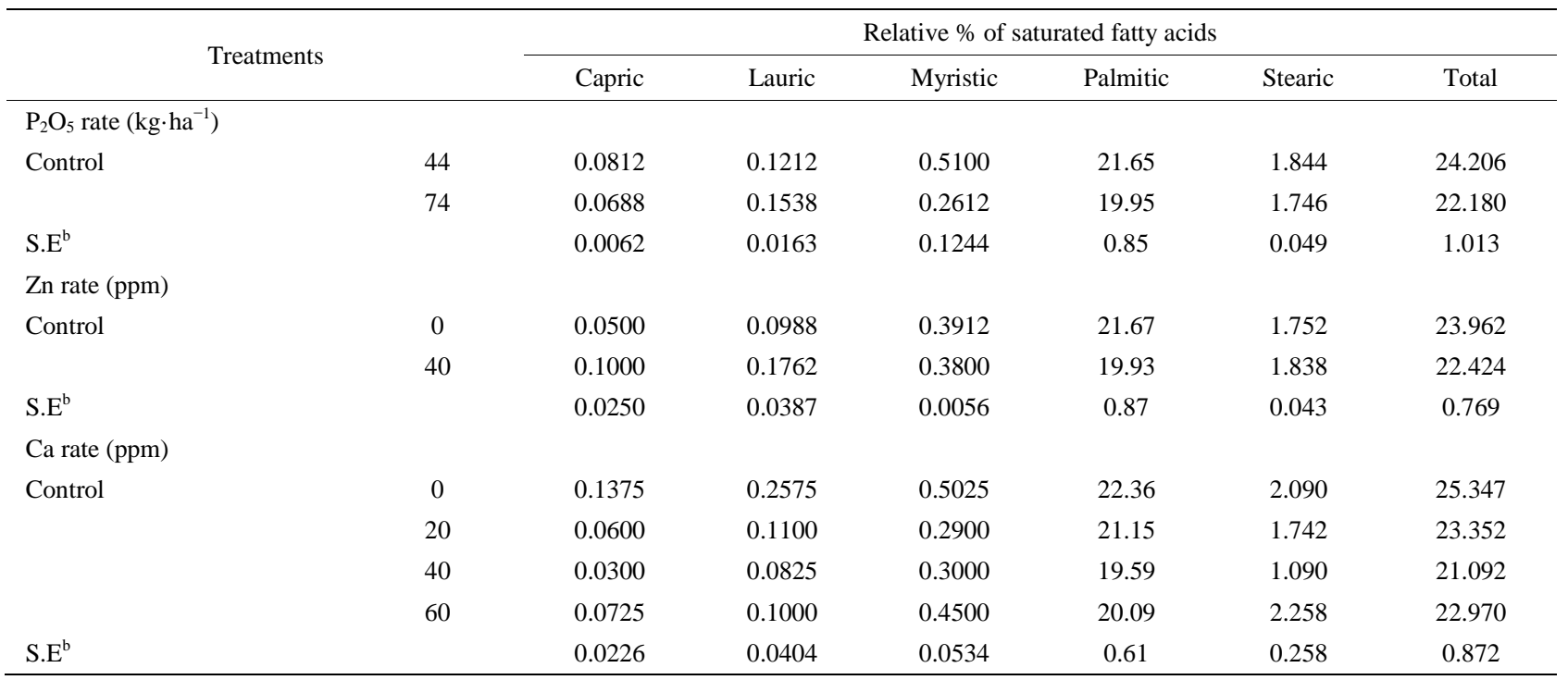

${ }^{\mathrm{a}}$ Mean data from a four replicate composite for the two seasons. ${ }^{\mathrm{b}}$ S.E. $=$ standard error [36].

saturated fatty acids decreased [36]. Calcium applied at all concentrations decreased in the saturated fatty acids capric, lauric, myristic, palmitic and stearica as well as the saturated fatty acids compared with the untreated control with one exception [36]. Spraying plants with Ca at $60 \mathrm{ppm}$ tended to increase stearic acid, compared with the control. Applied Ca at $40 \mathrm{ppm}$ gave the lowest capric, lauric, palmitic and stearic acids contents, compared with the other two concentrations (20 and $60 \mathrm{ppm}$ ). Calcium at $20 \mathrm{ppm}$ gave the lowest myristic acid content, compared with 40 and $60 \mathrm{ppm}$. The total unsaturated fatty acids (oleic and linoleic) and the ratio between total unsaturated fatty acids and total saturated fatty acids (TU/TS) were increased by raising $\mathrm{P}$ rate (Table 10 ).
Linoleic acid was the most abundant unsaturated fatty acid. Gushevilov and Palaveeva [76] studied the changes in sunflower oil contents of linoleic, oleic, stearic and palmitic acids due to application rate of phosphorus and found that oil quality remained high at a high $\mathrm{P}$ rate. The application of $\mathrm{Zn}$ resulted in an increase in total unsaturated fatty acids and TU/TS ratio, over the control [36]. Calcium applied at all rates increased the total unsaturated fatty acid and TU/TS ratio, compared with untreated control. Calcium at $40 \mathrm{ppm}$ gave the highest increment, total unsaturated fatty acid and TU/TS ratio, followed by $60 \mathrm{ppm}$ concentration. Spraying plants with $\mathrm{Ca}$ at $20 \mathrm{ppm}$ produced seed oil characterized by the highest oleic acid content, while spraying with 40 ppm 
gave the highest linoleic acid content, compared with the other concentrations [36].

\subsubsection{Cottonseed, Protein, Oil Yields, and Oil Properties as Influenced by K, P and Zn}

Seed yield $\mathrm{ha}^{-1}$ significantly increased when $\mathrm{K}$ was applied (by as much as 13.99\%) (Table 11) [1]. Potassium would have a favorable impact on yield compo- nents, including a number of open bolls plant ${ }^{-1}$ and boll weight, leading to a higher cotton yield. The role of $\mathrm{K}$ suggests that it affects abscission (reduced boll shedding) and it certainly affects yield [53]. Gormus [17]; Ibrahim et al. [13]; Gebaly [77] also found that $\mathrm{K}$ application increased yield. Application of Zn significantly increased seed yield ha ${ }^{-1}$, as compared with the untreated control (by 9.38\%) [1]. A possible explanation of such results

Table 10. Effect of $\mathrm{P}$ rate and foliar application of $\mathrm{Zn}$ and $\mathrm{Ca}$ on the relative percentage of unsaturated fatty acids ${ }^{\mathrm{a}}$.

\begin{tabular}{|c|c|c|c|c|c|}
\hline \multicolumn{2}{|c|}{ Treatments } & \multicolumn{3}{|c|}{ Relative \% of unsaturated fatty acids } & \multirow{2}{*}{$\begin{array}{c}\mathrm{TU} / \mathrm{TS}^{\mathrm{b}} \\
\text { ratio }\end{array}$} \\
\hline & & \multirow[t]{2}{*}{ Oleic } & \multirow[t]{2}{*}{ Linoleic } & \multirow[t]{2}{*}{ Total } & \\
\hline \multicolumn{3}{|c|}{$\mathrm{P}_{2} \mathrm{O}_{5}$ rate $\left(\mathrm{kg} \cdot \mathrm{ha}^{-1}\right)$} & & & \\
\hline \multirow[t]{2}{*}{ Control } & 44 & 21.89 & 53.90 & 75.79 & 3.13 \\
\hline & 74 & 21.91 & 55.91 & 77.82 & 3.51 \\
\hline S.E $E^{\mathrm{c}}$ & & 0.01 & 1.00 & 1.01 & 0.19 \\
\hline \multicolumn{6}{|c|}{ Zn rate (ppm) } \\
\hline \multirow[t]{2}{*}{ Control } & 0 & 21.70 & 54.33 & 76.03 & 3.17 \\
\hline & 40 & 22.09 & 55.48 & 77.57 & 3.46 \\
\hline S.E $E^{\mathrm{c}}$ & & 0.19 & 0.57 & 0.77 & 0.14 \\
\hline \multicolumn{6}{|c|}{ Ca rate (ppm) } \\
\hline \multirow[t]{4}{*}{ Control } & 0 & 21.34 & 53.31 & 74.65 & 2.94 \\
\hline & 20 & 22.26 & 54.38 & 76.64 & 3.28 \\
\hline & 40 & 22.00 & 56.90 & 78.90 & 3.74 \\
\hline & 60 & 22.00 & 55.02 & 77.02 & 3.35 \\
\hline S.E $\mathrm{E}^{\mathrm{c}}$ & & 0.19 & 0.75 & 0.87 & 0.16 \\
\hline
\end{tabular}

${ }^{\mathrm{a}}$ Mean data from a four replicate composite for the two seasons. ${ }^{\mathrm{b}} \mathrm{TU} / \mathrm{TS}$ ratio $=$ (total unsaturated fatty acids)/(total saturated fatty acids). ${ }^{\mathrm{C}} \mathrm{S}$.E. $=$ standard error [36].

Table 11. Effect of K rate and foliar application of $\mathrm{Zn}$ and foliar, additional $\mathrm{P}$ on cottonseed yield, seed index, seed oil, seed protein, oil and protein yields.

\begin{tabular}{|c|c|c|c|c|c|c|}
\hline Treatments & $\begin{array}{l}\text { Cottonseed yield } \\
\qquad\left(\mathrm{kg} \cdot \mathrm{ha}^{-1}\right)^{\mathrm{a}}\end{array}$ & $\begin{array}{l}\text { Seed index } \\
(\mathrm{g})^{\mathrm{a}}\end{array}$ & $\begin{array}{c}\text { Seed Oil } \\
(\%)^{\mathrm{b}}\end{array}$ & $\begin{array}{l}\text { Oil yield } \\
\left(\mathrm{kg} \cdot \mathrm{ha}^{-1}\right)^{\mathrm{b}}\end{array}$ & $\begin{array}{l}\text { Seed protein } \\
(\%)^{\mathrm{b}}\end{array}$ & $\begin{array}{c}\text { Protein yield } \\
\left(\mathrm{kg} \cdot \mathrm{ha}^{-1}\right)^{\mathrm{b}}\end{array}$ \\
\hline \multicolumn{7}{|l|}{ K rate $\left(\mathrm{kg} \cdot \mathrm{ha}^{-1}\right)$} \\
\hline 0 , control & 1828.0 & 10.01 & 19.55 & 357.5 & 22.24 & 406.6 \\
\hline 47.4 & 2083.8 & 10.16 & 19.82 & 413.2 & 22.27 & 464.1 \\
\hline L.S.D. $0.05^{c}$ & 80.6 & 0.05 & - & - & - & - \\
\hline S.D. ${ }^{c}$ & - & - & 0.15 & 34.2 & 0.03 & 36.2 \\
\hline \multicolumn{7}{|l|}{ Zn rate $\left(\mathrm{g} \cdot \mathrm{ha}^{-1}\right)$} \\
\hline 0 , control & 1868.3 & 10.04 & 19.59 & 366.2 & 22.25 & 415.7 \\
\hline 57.6 & 2043.5 & 10.13 & 19.78 & 404.4 & 22.26 & 455.0 \\
\hline L.S.D. $0.05^{c}$ & 80.6 & 0.05 & - & - & - & - \\
\hline S.D. ${ }^{c}$ & - & - & 0.18 & 40.5 & 0.04 & 42.6 \\
\hline \multicolumn{7}{|l|}{ P rate $\left(g \cdot h^{-1}\right)$} \\
\hline 0 , control & 1775.8 & 9.97 & 19.56 & 347.5 & 22.23 & 394.8 \\
\hline 576 & 1944.3 & 10.08 & 19.64 & 382.1 & 22.25 & 432.7 \\
\hline 1152 & 2023.7 & 10.13 & 19.76 & 400.3 & 22.26 & 450.5 \\
\hline 1728 & 2079.8 & 10.16 & 19.77 & 411.5 & 22.28 & 463.3 \\
\hline L.S.D. $0.05^{\mathrm{c}}$ & 114.0 & 0.07 & - & - & - & - \\
\hline S.D. ${ }^{\mathrm{c}}$ & - & - & 0.20 & 40.2 & 0.04 & 41.7 \\
\hline
\end{tabular}

${ }^{\mathrm{a} C o m b i n e d ~ s t a t i s t i c a l ~ a n a l y s i s ~ f r o m ~ t h e ~ t w o ~ s e a s o n s . ~}{ }^{\mathrm{b}}$ Mean data from a four replicate composites for the two seasons. ${ }^{\mathrm{c}} \mathrm{L} . \mathrm{S} . \mathrm{D}$. $=$ least significant differences. ${ }^{\mathrm{d}}$ S.D. = standard deviation was used to conduct t-test to verify the significance between every two treatment means at 0.05 level [1]. 
might be the improvement of yield components due to the application of $\mathrm{Zn}$. Zinc could have a favorable effect on photosynthetic activity of leaves [22], which improves mobilization of photosynthates and directly influences boll weight. Further, $\mathrm{Zn}$ is required in the synthesis of tryptophan, a precursor of indole-3-acetic acid [23], which is the major hormone, inhibits abscission of squares and bolls. Thus the number of retained bolls plant $^{-1}$ and consequently seed yield ha ${ }^{-1}$ would be increased [24]. Similar results were obtained by Ibrahim et al. [13]. Phosphorus extra foliar application at all the three concentrations (576, 1152 and $1728 \mathrm{~g}$ of $\mathrm{P} \mathrm{ha}^{-1}$ ) also significantly increased seed yield $\mathrm{ha}^{-1}$, where the three concentrations applied proved to excel the control (by $9.49 \%-17.12 \%$ ). The best yield was obtained at the highest $P$ concentration tested [1]. Such results reflect the pronounced improvement of yield components due to application of $\mathrm{P}$ which is possibly ascribed to its involvement in photosynthesis and translocation of carbohydrates to young bolls [9]. Phosphorus as a constituent of cell nucleus is essential for cell division and the development of meristematic tissue and hence it would have a stimulating effect on increasing the number of flowers and bolls plant ${ }^{-1}$ [78]. These results agree with that reported by Ibrahim et al. [13]; Saleem et al. [67]; Gebaly and El-Gabiery [14].

Seed index significantly increased with applying $\mathrm{K}$ (Table 11) [1]. A possible explanation for the increased seed index due to the application of $\mathrm{K}$ may be due in part to its favorable effects on photosynthetic activity rate of crop leaves and $\mathrm{CO}_{2}$ assimilation [15], which improves mobilization of photosynthates and directly influences boll weight which in turn directly affects seed weight [79]. The application of Zn significantly increased seed index, as compared to control [1]. The increased seed weight might be due to an increased photosynthesis activity resulting from the application of Zn [22] which improves mobilization of photosynthates and the amount of photosynthate available for reproductive sinks and thereby influences boll weight, factors that coincide with increased in seed weight [24]. The phosphorus applied at all three rates significantly increased seed index over the control. The highest rate of $\mathrm{P}\left(1728 \mathrm{~g} \cdot \mathrm{ha}^{-1}\right)$ showed the highest numerical value of seed index [1]. This increased seed weight may be due to the fact that $\mathrm{P}$ activated the biological reaction in cotton plant, particularly photosynthesis fixation of $\mathrm{CO}_{2}$ and synthesis of sugar, and other organic compounds $[22,80]$. This indicates that treated cotton bolls had larger photosynthetically supplied sinks for carbohydrates and other metabolites than untreated bolls [1].

The applied $\mathrm{K}$ caused significant increase in seed oil content and oil yield ha ${ }^{-1}\left(55.7 \mathrm{~kg}\right.$ oil ha $\left.{ }^{-1}\right)$, compared with untreated control (Table 11) [1]. This could be at- tributed to the role of $\mathrm{K}$ in biochemical pathways in plants. Potassium increases the photosynthetic rates of crop leaves, $\mathrm{CO}_{2}$ assimilation and facilitates carbon movement [15]. The favorable effects of $\mathrm{K}$ on seed oil content and oil yield were mentioned by Ibrahim et al. [13]; Gebaly [77]. Spraying plants with Zn resulted in an increase in seed oil content and oil yield ha ${ }^{-1}$ (38.2 kg oil $\mathrm{ha}^{-1}$ ), compared with the untreated control. Cakmak [81] has speculated that Zn deficiency stress may inhibit some antioxidant enzymes, resulting in extensive oxidative damage to membrane lipids. Similar results were obtained by Ibrahim et al. [13]. The foliar application of $\mathrm{P}$ at all the three concentrations tended to increase the seed oil content and oil yield ha ${ }^{-1}$ (34.6 - $64.0 \mathrm{~kg}$ oil ha ${ }^{-1}$ ), over the control [1]. The effect was the most significant at the highest $\mathrm{P}$ concentration $\left(1728 \mathrm{~g} \cdot \mathrm{ha}^{-1}\right)$ on oil yield $\mathrm{ha}^{-1}$. These results agree with those obtained by Ibrahim et al. [13]; Gebaly and El-Gabiery [14].

The applied K caused a slight increase in seed protein content and significantly increased protein yield $\mathrm{ha}^{-1}$ (57.5 kg protein ha ${ }^{-1}$ ), compared with the untreated control (Table 11) [1]. It also increased the protein yield $\mathrm{ha}^{-1}$, resulting in an improvement in both seed yield and seed protein content. This could be attributed to the role of $\mathrm{K}$ in biochemical pathways in plants. Potassium increases the photosynthetic rates of crop leaves, $\mathrm{CO}_{2}$ assimilation and facilitates carbon movement [15]. Also, $\mathrm{K}$ has favorable effects on metabolism of nucleic acids, and proteins [82]. These are manifested in metabolites formed in plant tissues and directly influence the growth and development processes. Similar results were obtained by Ibrahim et al. [13]; Gebaly [77]. The application of Zn slightly increased the seed protein content, and increased protein yield ha ${ }^{-1}$ (39.3 $\mathrm{kg}_{\text {protein }} \mathrm{ha}^{-1}$ ) numerically compared with the untreated control. Because $\mathrm{Zn}$ is directly involved in both gene expression and protein synthesis. Cakmak [81] has speculated that Zn deficiency stress may inhibit the activities of a number of antioxidant enzymes, resulting in extensive oxidative damage to proteins, chlorophyll and nucleic acids. These results agree with those reported by Ghourab et al. [79]. Phosphorus applied at all rates tended to increase the seed protein content and the protein yield ha ${ }^{-1}$ (37.9-68.5 $\mathrm{kg}$ protein $\mathrm{ha}^{-1}$ ) compared with the untreated control [1]. The effect was significant on protein yield $\mathrm{ha}^{-1}$ when applied the high P concentration (1728 g.ha ${ }^{-1}$ ), resulting from an improvement in both seed yield and seed protein content. Phosphorus is a component of nucleic acids, which are necessary for protein synthesis [8]. Similar results were obtained by Gebaly and El-Gabiery [14].

The oil refractive index, unsaponifiable matter and iodine value significantly increased, while saponification value significantly decreased by applied $\mathrm{K}$, compared with the untreated control (Table 12) [1]. On the other 
Table 12. Effect of K rate and foliar application of $\mathrm{Zn}$ and foliar, additional $\mathrm{P}$ on seed oil properties ${ }^{\mathrm{a}}$.

\begin{tabular}{|c|c|c|c|c|c|}
\hline Treatments & Refractive index & Acid value & Saponification value & Unsaponifiable matter (\%) & Iodine value \\
\hline \multicolumn{6}{|l|}{$\mathrm{K}$ rate $\left(\mathrm{kg} \cdot \mathrm{ha}^{-1}\right)$} \\
\hline 0 , control & 1.4684 & 0.1343 & 190.81 & 0.3538 & 127.48 \\
\hline 47.4 & 1.4698 & 0.1316 & 189.74 & 0.3950 & 132.76 \\
\hline S.D ${ }^{b}$ & 0.0013 & 0.0032 & 0.74 & 0.0223 & 3.63 \\
\hline \multicolumn{6}{|l|}{ Zn rate $\left(\mathrm{g} \cdot \mathrm{ha}^{-1}\right)$} \\
\hline 0 , control & 1.4683 & 0.1336 & 190.71 & 0.3625 & 128.39 \\
\hline 57.6 & 1.4699 & 0.1323 & 189.84 & 0.3863 & 131.85 \\
\hline S.D ${ }^{b}$ & 0.0012 & 0.0034 & 0.80 & 0.0287 & 4.21 \\
\hline \multicolumn{6}{|l|}{ P rate $\left(\mathrm{g} \cdot \mathrm{ha}{ }^{-1}\right)$} \\
\hline 0 , control & 1.4681 & 0.1350 & 190.75 & 0.3525 & 125.33 \\
\hline 576 & 1.4693 & 0.1343 & 190.33 & 0.3725 & 131.46 \\
\hline 1152 & 1.4696 & 0.1323 & 190.10 & 0.3800 & 131.93 \\
\hline 1728 & 1.4695 & 0.1309 & 189.92 & 0.3925 & 131.76 \\
\hline S.D ${ }^{b}$ & 0.0015 & 0.0033 & 0.94 & 0.0294 & 3.80 \\
\hline
\end{tabular}

${ }^{\mathrm{a}}$ Mean data from a four replicate composites for the two seasons. ${ }^{\mathrm{b}}$ S.D. = standard deviation [1].

hand, the acid value was not significantly affected due to the $\mathrm{K}$ application. Potassium is an essential nutrient and an integral component of several important compounds in plant cells. This attributed to the role of $\mathrm{K}$ in biochemical pathways in plants [83]. These may be reflected in distinct changes in seed oil quality. Mekki et al. [84] stated that, foliar application with $\mathrm{K}\left(0\right.$ or $\left.3.5 \% \mathrm{~K}_{2} \mathrm{O}\right)$ on sunflower at the seed-filling stage resulted in decreased oil acid content. Froment et al. [85], in linseed, found that the iodine value, which indicates the degree of unsaturation in the final oil, was highest in treatments receiving extra K. Spraying plants with $\mathrm{Zn}$ resulted in a significant increase in oil refractive index, and a significant decrease in unsaponifiable matter, compared with untreated control. The other oil properties (acid, saponification, and iodine values) were not significantly affected. Zinc activates a large number of enzymes, either due to binding enzymes and substrates, or the effects of $\mathrm{Zn}$ on conformation of enzymes or substrate, or both $[86,87]$. These would have a direct impact through utilization in the growth processes, which are reflected in distinct changes in seed oil quality [1]. The application of $\mathrm{P}$ at all concentrations significantly increased iodine value, compared with the untreated control, while the other oil properties (oil refractive index; acid and saponification values, and the unsaponifiable matter) were not significantly affected.

The applied $\mathrm{K}$ decreased the oil-saturated fatty acids (capric, lauric, myristic, palmitic, and stearic) (Table 13) [1]. A significant effect was found only on capric, palmitic, and the total saturated fatty acids. The total unsaturated fatty acids (oleic and linoleic) and the ratio between total unsaturated fatty acids and total saturated fatty acids (TU/TS) were increased (by 4.31, and 19.77\%, respectively) by applied K (Table 14) [1]. The effect was significant on linoleic acid, the total unsaturated fatty acids (oleic and linoleic), and TU/TS ratio. The beneficial effect of applied $\mathrm{K}$ on TU and TU/TS ratio may be due to the regulated effect of $\mathrm{K}$, which acts as an activator on many enzymatic processes, where some of these enzymes may affect the seed oil content from these organic matters. To our knowledge, no information on the effect of $\mathrm{K}$ on the cottonseed oil fatty acids is available in the literatures [1]. Mekki et al. [84] stated that, foliar application with $\mathrm{K}$ on sunflower increased the oleic acid fatty acid. Froment et al. [85], in linseed oil, found that the linoleic acid content was greatest in treatment receiving extra $\mathrm{K}$. The application of $\mathrm{Zn}$ resulted in a decrease of the saturated fatty acids, i.e. palmitic, capric, myristic, and stearic, and the total, but resulted in an increase in lauric acid, compared to the untreated control [1]. The effect was significant only on palmitic acid, and the total saturated fatty acids in the oil. The application of $\mathrm{Zn}$ resulted in an increase in the total unsaturated fatty acids (by 3.49\%) and TU/TS ratio (by 15.25\%), over the control. The effect was significant on oleic acid, the total unsaturated fatty acids (oleic and linoleic), and TU/TS ratio. The stimulatory residual effects of the application $\mathrm{Zn}$ on TU and TU/TS ratio were probably due to the favorable effects of $\mathrm{Zn}$ on fundamental metabolic reactions in plant tissues. Phosphorus applied at all concentrations resulted in a decrease in the total saturated fatty acids compared with the untreated control. Spraying plants with $\mathrm{P}$ at $1728 \mathrm{~g} \cdot \mathrm{ha}^{-1}$ gave the lowest total saturated fatty acids oil, followed by $\mathrm{P}$ at $1152 \mathrm{~g} \cdot \mathrm{ha}^{-1}$ concentration, compared with the control [1]. Application the high $\mathrm{P}$ concentration (1728 $\mathrm{g} \cdot \mathrm{ha}^{-1}$ ) gave the lowest capric, lauric, palmitic, and stearic acid contents compared with the 
Table 13. Effect of $\mathrm{K}$ rate and foliar application of $\mathrm{Zn}$ and foliar, additional $\mathrm{P}$ on the relative percentage of saturated fatty acids ${ }^{\mathrm{a}}$.

\begin{tabular}{|c|c|c|c|c|c|c|}
\hline \multirow{2}{*}{ Treatments } & \multicolumn{6}{|c|}{ Relative $\%$ of saturated fatty acids } \\
\hline & Capric & Lauric & Myristic & Palmitic & Stearic & Total \\
\hline \multicolumn{7}{|l|}{$\mathrm{K}$ rate $\left(\mathrm{kg} \cdot \mathrm{ha}^{-1}\right)$} \\
\hline 0 , control & 0.0774 & 0.0626 & 0.8275 & 22.21 & 2.271 & 25.452 \\
\hline 47.4 & 0.0728 & 0.0599 & 0.4863 & 19.72 & 1.915 & 22.250 \\
\hline S.D $\mathrm{D}^{\mathrm{b}}$ & 0.0036 & 0.0079 & 0.3407 & 1.48 & 0.451 & 2.331 \\
\hline \multicolumn{7}{|l|}{ Zn rate $\left(\mathrm{g} \cdot \mathrm{ha}^{-1}\right)$} \\
\hline 0 , control & 0.0769 & 0.0609 & 0.6763 & 22.16 & 2.185 & 25.159 \\
\hline 57.6 & 0.0733 & 0.0616 & 0.6375 & 19.77 & 2.001 & 22.544 \\
\hline S.D $D^{b}$ & 0.0040 & 0.0049 & 0.3859 & 1.79 & 0.479 & 2.532 \\
\hline \multicolumn{7}{|l|}{ P rate $\left(g \cdot h a^{-1}\right)$} \\
\hline 0, control & 0.0795 & 0.0665 & 1.1075 & 22.80 & 2.728 & 26.776 \\
\hline 576 & 0.0748 & 0.0623 & 0.5925 & 20.70 & 1.855 & 23.287 \\
\hline 1152 & 0.0733 & 0.0595 & 0.4375 & 20.30 & 1.905 & 22.770 \\
\hline 1728 & 0.0728 & 0.0568 & 0.4900 & 20.07 & 1.885 & 22.572 \\
\hline S.D $D^{b}$ & 0.0036 & 0.0034 & 0.2826 & 2.02 & 0.317 & 2.422 \\
\hline
\end{tabular}

${ }^{\mathrm{a}}$ Mean data from a four replicate composites for the two seasons. ${ }^{\mathrm{b}}$ S.D. = standard deviation [1].

Table 14. Effect of K rate and foliar application of $\mathrm{Zn}$ and foliar, additional $\mathrm{P}$ on the relative percentage of unsaturated fatty acids ${ }^{\mathrm{a}}$.

\begin{tabular}{|c|c|c|c|c|}
\hline \multirow{2}{*}{ Treatments } & \multicolumn{3}{|c|}{ Relative $\%$ of unsaturated fatty acids } & \multirow{2}{*}{$\begin{array}{c}\mathrm{TU} / \mathrm{TS}^{\mathrm{b}} \\
\text { ratio }\end{array}$} \\
\hline & Oleic & Linoleic & Total & \\
\hline \multicolumn{5}{|l|}{$\mathrm{K}$ rate $\left(\mathrm{kg} \cdot \mathrm{ha}^{-1}\right)$} \\
\hline 0 , control & 21.61 & 52.94 & 74.54 & 2.954 \\
\hline 47.4 & 22.73 & 55.01 & 77.75 & 3.538 \\
\hline S.D ${ }^{c}$ & 1.40 & 1.49 & 2.33 & 0.403 \\
\hline \multicolumn{5}{|l|}{ Zn rate $\left(\mathrm{g} \cdot \mathrm{ha}^{-1}\right)$} \\
\hline 0 , control & 21.43 & 53.40 & 74.84 & 3.016 \\
\hline 57.6 & 22.90 & 54.55 & 77.45 & 3.476 \\
\hline S.D ${ }^{c}$ & 1.31 & 1.76 & 2.53 & 0.446 \\
\hline \multicolumn{5}{|l|}{$\mathrm{P}$ rate $\left(\mathrm{g} \cdot \mathrm{ha}^{-1}\right)$} \\
\hline 0 , control & 21.11 & 52.11 & 73.22 & 2.755 \\
\hline 576 & 21.96 & 54.75 & 76.70 & 3.331 \\
\hline 1152 & 22.52 & 54.70 & 77.23 & 3.427 \\
\hline 1728 & 23.09 & 54.33 & 77.43 & 3.472 \\
\hline S.D ${ }^{c}$ & 1.42 & 1.57 & 2.42 & 0.439 \\
\hline
\end{tabular}

${ }^{\mathrm{a}}$ Mean data from a four replicate composite for the two seasons. ${ }^{\mathrm{b}} \mathrm{TU} / \mathrm{TS}$ ratio = (total unsaturated fatty acids)/(total saturated fatty acids). ${ }^{\mathrm{c}} \mathrm{S} . \mathrm{D}$. $=$ standard deviation [1].

other two concentrations (576 and $1152 \mathrm{~g}$ of $\mathrm{P} \mathrm{ha}{ }^{-1}$ ), while applied $\mathrm{P}$ at $1152 \mathrm{~g} \cdot \mathrm{ha}^{-1}$ gave the lowest myristic acid content compared with the other two concentrations (576 and $1728 \mathrm{~g}$ of $\mathrm{P} \mathrm{ha}^{-1}$ ). The effect was significant for the two concentrations1152 and $1728 \mathrm{~g}$ of $\mathrm{P} \mathrm{ha}^{-1}$ on capric acid and the total saturated fatty acids in the oil, and for all different $\mathrm{P}$ concentrations on lauric, myristic, and stearic. Phosphorus applied at all rates increased the total unsaturated fatty acid (by 4.77\% - 5.75\%) and TU/TS ratio (by 20.91\% - 26.03\%) compared with the untreated control. Applied P at $1728 \mathrm{~g} \cdot \mathrm{ha}^{-1}$ gave the highest increment, followed by the concentration $1152 \mathrm{~g}$ of $\mathrm{P} \mathrm{ha}^{-1}$ [1]. Spraying plants with P at $1728 \mathrm{~g} \cdot \mathrm{ha}^{-1}$ produced seed oil characterized by the highest oleic acid content, while spraying with $576 \mathrm{~g}$ of $\mathrm{P} \mathrm{ha}{ }^{-1}$ gave the highest linoleic acid content compared with the other concentrations. The effect was significant for the high P concentration (1728 $\mathrm{g} \cdot \mathrm{ha}^{-1}$ ) on oleic, for the two concentrations, i.e., 1152 and $1728 \mathrm{~g}$ of $\mathrm{P} \mathrm{ha}^{-1}$ on the TU/TS ratio, and for all different concentrations on linoleic, and the total unsaturated fatty acid [1]. The beneficial effect of applied $\mathrm{P}$ at different concentrations on TU and TU/TS ratio may be due to the regulated effect of $\mathrm{P}$ on many enzymatic processes and the fact that $\mathrm{P}$ acts as an activator of some enzymes which may affect the seed oil fatty acids composition. Gushevilov and Palaveeva [76] studied the 
changes in the contents of linoleic, oleic, stearic, and palmitic acids in sunflower oil due to the P-application rate and found that oil quality remained high at a high P-rate. Khan et al. [88] indicated that oleic acid increased by increasing levels of $\mathrm{P}$ added to rapeseed mustard.

\subsubsection{Effects N, K and PGR on Oil Content and Quality of Cotton Seed}

The seed yield of cotton significantly $(P<0.05)$ increased (as much as $13.03 \%$ ) by increasing $\mathrm{N}$-application rate from 95.2 to $142.8 \mathrm{~kg} \cdot \mathrm{ha}^{-1}$ (Table 15) [37]. There is an optimal relationship between the nitrogen content in the plant and $\mathrm{CO}_{2}$ assimilation, where decreases in $\mathrm{CO}_{2}$ fixation are well documented for $\mathrm{N}$-deficient plants. Nitrogen deficiency is associated with elevated levels of ethylene (which increase boll shedding), suggesting ethylene production in response to $\mathrm{N}$-deficiency stress [89]. Nitrogen is also an essential nutrient in creating plant dry matter, as well as many energy-rich compounds which regulate photosynthesis and plant production, thus influencing boll development, increasing the number of bolls per plant and boll weight. Similar findings were obtained by McConnell and Mozaffari [90] and Saleem et al. [46] when $\mathrm{N}$ fertilizer was applied at $120 \mathrm{~kg} \cdot \mathrm{ha}^{-1}$ and Wiatrak et al. [80] when $\mathrm{N}$ fertilizer was applied at 67 - $202 \mathrm{~kg} \cdot \mathrm{ha}^{-1}$. Also, similar results were obtained by Sarwar Cheema et al. [33]; Hamed et al. [47]. On the other hand Boquet (2005) reported that increasing $\mathrm{N}$ from 90 to $157 \mathrm{~kg} \cdot \mathrm{ha}^{-1}$ did not result in increased cotton yield in irrigated or rain-fed cotton. Foliar application of K significantly increased seed yield by $10.02 \%$ to $16.25 \%$ as compared to the control $\left(0 \mathrm{~g} \cdot \mathrm{K} \cdot \mathrm{ha}^{-1}\right)$ (Table 15) [37]. The differences between the effects of the three concerned $\mathrm{K}$ rates were statistically insignificant; with the exception of the $957 \mathrm{~g} \cdot \mathrm{K} \cdot \mathrm{ha}^{-1}$ concentration that proved to produce significantly higher seed yield ha ${ }^{-1}$ (5.66\%) than the $319 \mathrm{~g} \cdot \mathrm{K} \cdot \mathrm{ha}^{-1}$ concentration. These increases could be due to the favorable effects of this nutrient on yield components such as number of opened bolls plant ${ }^{-1}$, boll weight, or both, leading to higher cotton yield. Zeng [53] indicated that, $\mathrm{K}$ fertilizer reduced boll shedding. Pettigrew [91] stated that, the elevated carbohydrate concentrations remaining in source tissue, such as leaves, appear to be part of the overall effect of $\mathrm{K}$ deficiency in reducing the amount of photosynthate available for reproductive sinks and thereby producing changes in boll weight. Cakmak et al. [92] found that, the K nutrition had pronounced effects on carbohydrate partitioning by affecting either the phloem export of photosynthates (sucrose) or growth rate of sink and/or source organs. Mullins et al. [93] evaluated cotton yield under a long-term soil application of $\mathrm{K}$ at $75-225 \mathrm{~kg} \mathrm{~K}_{2} \mathrm{O}$ ha $^{-1}$, and found that $\mathrm{K}$ application increased yield. Results obtained here confirmed those obtained by Aneela et al. [18] when applying $200 \mathrm{~kg} \mathrm{~K}_{2} \mathrm{O} \mathrm{ha}^{-1}$, Pervez et al. [19] under 62.5, 125, $250 \mathrm{~kg} \cdot \mathrm{K} \cdot \mathrm{ha} \cdot \mathrm{ha}^{-1}$, Pettigrew et al. [20] under $\mathrm{K}$

Table 15. Effect of soil application of $\mathrm{N}$ and foliar application of $\mathrm{K}$ and mepiquat chloride (MC) on the yield, 100-seed weight, oil and protein of the cotton.

\begin{tabular}{|c|c|c|c|c|c|c|}
\hline Treatments & $\begin{array}{l}\text { Cottonseed yield } \\
\left(\mathrm{kg} \cdot \mathrm{ha}^{-1}\right)^{\mathrm{a}}\end{array}$ & $\begin{array}{l}\text { 100-seed weight } \\
(\mathrm{g})^{\mathrm{a}}\end{array}$ & $\begin{array}{c}\text { Seed oil } \\
(\%)^{\mathrm{b}}\end{array}$ & $\begin{array}{l}\text { Oil yield } \\
\left(\mathrm{kg} \cdot \mathrm{ha}^{-1}\right)^{\mathrm{b}}\end{array}$ & $\begin{array}{c}\text { Seed protein } \\
(\%)^{\mathrm{b}}\end{array}$ & $\begin{array}{l}\text { Protein yield } \\
\left(\mathrm{kg} \cdot \mathrm{ha}^{-1}\right)^{\mathrm{b}}\end{array}$ \\
\hline \multicolumn{7}{|l|}{$\mathrm{N}$ rate $\left(\mathrm{kg} \cdot \mathrm{ha}^{-1}\right)$} \\
\hline 95.2 & 1862.4 & 10.09 & 19.73 & 367.5 & 22.24 & 414.2 \\
\hline 142.8 & 2105.0 & 10.32 & 19.60 & 413.0 & 22.44 & 472.2 \\
\hline L.S.D. $0.05^{\mathrm{c}}$ & 78.7 & 0.07 & - & - & - & - \\
\hline S.D. ${ }^{\mathrm{c}}$ & - & - & 0.16 & 33.6 & 0.11 & 35.5 \\
\hline \multicolumn{7}{|l|}{ K rate $\left(\mathrm{g} \cdot \mathrm{ha}^{-1}\right)$} \\
\hline 0 & 1804.4 & 10.03 & 19.49 & 351.6 & 22.32 & 402.9 \\
\hline 319 & 1985.2 & 10.19 & 19.61 & 389.3 & 22.32 & 443.1 \\
\hline 638 & 2047.7 & 10.27 & 19.73 & 404.2 & 22.34 & 457.7 \\
\hline 957 & 2097.6 & 10.32 & 19.83 & 415.8 & 22.37 & 469.3 \\
\hline L.S.D. $0.05^{\mathrm{c}}$ & 111.4 & 0.10 & - & - & - & - \\
\hline S.D. ${ }^{c}$ & - & - & 0.12 & 35.0 & 0.16 & 41.8 \\
\hline \multicolumn{7}{|l|}{ MC rate $\left(\mathrm{g} \cdot \mathrm{ha}^{-1}\right)$} \\
\hline 0 & 1891.8 & 10.13 & 19.61 & 371.1 & 22.31 & 422.1 \\
\hline $48+24$ & 2075.6 & 10.27 & 19.72 & 409.4 & 22.37 & 464.4 \\
\hline L.S.D. $0.05^{\mathrm{c}}$ & 78.7 & 0.075 & - & - & - & - \\
\hline S.D. ${ }^{d}$ & - & - & 0.17 & 36.1 & 0.15 & 41.3 \\
\hline
\end{tabular}

${ }^{\mathrm{a}}$ Combined statistical analysis from the two seasons. ${ }^{\mathrm{b}}$ Mean data from a four replicate composites for the two seasons. ${ }^{\mathrm{c}} \mathrm{L}$.S.D. $=$ least significant differences, ${ }^{\mathrm{d}}$ S.D. = standard deviation was used to conduct t-test to verify the significance between every two treatment means at 0.05 level [37]. 
fertilizer (112 $\left.\mathrm{kg} \cdot \mathrm{ha}^{-1}\right)$; Gebaly [77]. Application of the PGR mepiquat chloride significantly increased seed yield ha $^{-1}$ (by 9.72\%), as compared with untreated plants. Such increases could be due to the fact that, the application of mepiquat chloride restrict vegetative growth and thus enhance reproductive organs by allowing plants to direct more energy towards the reproductive structure [51]. This means that bolls on treated cotton would have a larger photo synthetically supplied sink of carbohydrates and other metabolites than did those on untreated cotton [30]. Results agreed with those obtained by Prakash et al. [94] when mepiquat chloride was applied at 50 ppm, Mekki [95] when mepiquat chloride was applied at $100 \mathrm{ppm}$, and Kumar et al. [31]. Also, similar results were obtained by Sarwar Cheema et al. [33]; Gebaly and El-Gabiery [14].

Seed weight significantly increased by adding the high $\mathrm{N}$-rate (Table 15) [37]. This may be due to increased photosynthetic activity that increases accumulation of metabolites, with direct impact on seed weight. Reddy et al. [2], in a pot experiment under natural environmental conditions, where 20-day old cotton plants received 0 , $0.5,1.5$ or $6 \mathrm{mM} \mathrm{NO}_{3}$, found that, net photosynthetic rates, stomatal conductance and transpiration were positively correlated with leaf $\mathrm{N}$ concentration. Similar findings were reported by Palomo et al. [96], when $\mathrm{N}$ was applied at $40-200 \mathrm{~kg} \cdot \mathrm{ha}^{-1}$; Ali and El-Sayed [97], when $\mathrm{N}$ was applied at 95 to $190 \mathrm{~kg} \cdot \mathrm{ha}^{-1}$; Hamed et al. [47] when $\mathrm{N}$ was applied up to $178 \mathrm{~kg} \cdot \mathrm{ha}^{-1}$. 100 -seed weight significantly increased with $\mathrm{K}$ application at all the three concentrations as compared to the control [37]. The highest rate of $\mathrm{K}\left(957 \mathrm{~g} \cdot \mathrm{K} \cdot \mathrm{ha}^{-1}\right)$ resulted the highest seed weight. The difference between the high rate and low rate $\left(319 \mathrm{~g} \cdot \mathrm{K} \cdot \mathrm{ha}^{-1}\right)$ was also significant. Increase in seed weight might be due to the effect of $\mathrm{K}$ on mobilization of photosynthates, which would directly influence boll weight and increase seed weight [38,91]. Ibrahim et al. [13] reported that, the application of $\mathrm{K}$ fertilizer resulted in an increase in seed weight. The application of mepiquat chloride significantly increased 100 -seed weight as compared to the plots that had not received mepiquat chloride, the untreated control [37]. Increased seed weight as a result of mepiquat chloride applications may be due to an increase in photosynthetic activity, which stimulates photosynthetic activity, and dry matter accumulation [31,82], and in turn increases the formation of fully-mature seed and thus increases seed weight. Similar results to the present study were obtained by Ghourab et al. [79]; Lamas [98].

Seed oil content was slightly decreased with an increase in the $\mathrm{N}$ rate from 95.2 to $142.8 \mathrm{~kg} \cdot \mathrm{ha}^{-1}$, but seed oil yield $\mathrm{ha}^{-1}$ had significantly increased $(45.5 \mathrm{~kg}$ oil $\mathrm{ha}^{-1}$ ), which is attributed to the significant increase in seed yield (Table 15) [37]. Similar results were obtained by Froment et al. [85], in linseed; Zubillaga et al. [99] in sunflower. Yield increases in this study were attributed to the fact that $\mathrm{N}$ was an important nutrient in controlling new growth, thus influencing boll development, increasing the number of bolls plant ${ }^{-1}$ and boll weight. Synthesis of fat requires both $\mathrm{N}$ and carbon skeletons during the course of seed development [5]. The application of $\mathrm{K}$ at all the three concentrations tended to increase seed oil content and yield over the control (37.7 - $64.2 \mathrm{~kg}$ oil $\mathrm{ha}^{-1}$ ), but was statistically significant only for 638 and $957 \mathrm{~g} \cdot \mathrm{K} \cdot \mathrm{ha}^{-1}$ concentrations on the seed oil content, and with $\mathrm{K}$ application at all the three concentrations on the oil yield ha ${ }^{-1}$ [37]. The highest rate of $\mathrm{K}\left(957 \mathrm{~g} \cdot \mathrm{K} \cdot \mathrm{ha}^{-1}\right)$ showed the highest numerical values of seed oil content and oil yield $\mathrm{ha}^{-1}$ compared with the other two concentrations (319 and $638 \mathrm{~g} \cdot \mathrm{K} \cdot \mathrm{ha}^{-1}$ ) [37]. This could be attributed to the role of $\mathrm{K}$ in biochemical pathways in plants. Pettigrew [91] stated that, the elevated carbohydrate concentrations remaining in source tissue, such as leaves, appear to be part of the overall effect of K deficiency in reducing the amount of photosynthate available for reproductive sinks and thereby producing changes in yield and quality found in cotton. Madraimov [100] indicated that, increasing the rates of applied $\mathrm{K}_{2} \mathrm{O}$ from 0 to $150 \mathrm{~kg} \cdot \mathrm{ha}^{-1}$ produced linear increases in cottonseed oil contents. Previously, favorable effects of K on seed oil content and oil yield were mentioned by Ibrahim et al. [13]; Gebaly [77]. They reported that, increasing $\mathrm{K}$ supply to maternal cotton plants increased crude fat content of seed. The application of mepiquat chloride resulted in an insignificant increase in seed oil content over that of the control [37]. Also significantly increased the seed oil yield $\mathrm{ha}^{-1}$ compared with the untreated control (by $38.3 \mathrm{~kg}$ oil ha $^{-1}$ ). These results could be attributed to the increase of total photoassimilates (e.g. lipids) and the translocated assimilates to the sink as a result of applying mepiquat chloride [101]. This result agreed with those obtained by Gebaly and El-Gabiery [14].

High N-rate significantly increased the seed protein content and yields (58.0 kg protein ha ${ }^{-1}$ ) (Table 15) [37]. Stitt [102] indicated that, nitrate $\left(\mathrm{NO}_{3}^{-}\right)$induces genes involved in different aspects of carbon metabolism, including the synthesis of organic acids used for amino acid synthesis. These results suggest that the highest $\mathrm{N}$ rate of the added $\mathrm{N}$ in this study compared with the lowest rate increases the amino acids synthesis in the leaves and this stimulate the accumulation of protein in the seed. The present results confirmed the findings of Patil et al. [34]. Averaged seed protein content tended to increase when applying 638 and $957 \mathrm{~g} \cdot \mathrm{K} \cdot \mathrm{ha}^{-1}$ compared with untreated control $\left(0 \mathrm{~g} \cdot \mathrm{K} \cdot \mathrm{ha}^{-1}\right)$ [37]. Applied $\mathrm{K}$ at all rates also, increased the protein yield numerically (40.2 - 66.4 $\mathrm{kg}$ protein $\mathrm{ha}^{-1}$ ), resulting from an improvement in both seed yield and seed protein content. The increase in pro- 
tein yield ha ${ }^{-1}$ was statistically significant when applying the 638 and $957 \mathrm{~g} \cdot \mathrm{K} \cdot \mathrm{ha}^{-1}$ concentrations. Best protein yield was obtained at the high $\mathrm{K}$ concentration (957 $\mathrm{g} \cdot \mathrm{K} \cdot \mathrm{ha}^{-1}$ ) compared with the other two concentrations (319 and $638 \mathrm{~g} \cdot \mathrm{K} \cdot \mathrm{ha}^{-1}$ ) [37]. This could be attributed to the role of $\mathrm{K}$ in biochemical pathways in plants. Potassium has favorable effects on metabolism of nucleic acids and proteins [82]. These are manifested in metabolites formed in plant tissues, and directly influence the growth and development processes, thereby producing changes in yield and quality of cotton [37]. These results were in agreement with those obtained by Ibrahim et al. [13]; Gebaly [77]. Seed protein content tended to increase numerically, while seed protein yield was significantly increased (42.3 kg protein $\mathrm{ha}^{-1}$ ) in plants treated with mepiquat chloride as compared with the untreated plants. The increase in seed protein content and yield may be caused by the role of mepiquat chloride in protein synthesis, encouraging the conversion of amino acids into protein [62] along with the favorable and significant effect of mepiquat chloride on cottonseed yield. These results were confirmed by Gebaly and El-Gabiery [14].

The seed oil refractive index, unsaponifiable matter and iodine value tended to increase, while the oil saponification and acid values tended to decrease by raising N-rate (Table 16) [37]. Narang et al. [103] indicated that, $\mathrm{N}$ application increased the oil-quality index (iodine number) in rape. The application of $\mathrm{K}$ at different concentrations tended to increase the seed oil refractive index, unsaponifiable matter and iodine value, and to decrease the oil saponification value and acid value, numerically, compared with the untreated control, especially when applied $\mathrm{K}$ at the high concentration (957 $\mathrm{g} \cdot \mathrm{K} \cdot \mathrm{ha}^{-1}$ ) [37]. The effect was significant for the two concentrations 638 and $957 \mathrm{~g} \cdot \mathrm{K} \cdot \mathrm{ha}^{-1}$ on acid value, and unsaponifiable matter, and for all different concentrations on iodine value. The effect of $\mathrm{K}$ concentrations on oil refractive index was very limited. Potassium is an essential nutrient and an integral component of several important compounds in plant cells. This attributed to the role of $\mathrm{K}$ in biochemical pathways in plants, where $\mathrm{K}$ acts as an activator for several enzymes involved in carbohydrates metabolism [8]. These may be reflected in distinct changes in seed oil quality [37]. Mekki et al. [84] stated that, foliar application with $\mathrm{K}\left(0\right.$ or $\left.3.5 \% \mathrm{~K}_{2} \mathrm{O}\right)$ on sunflower at the seed-filling stage, decreased oil acid value. Froment et al. [85], when working with linseed found that, the iodine value, which indicates the degree of unsaturation of the final oil, was highest in treatment receiving extra $\mathrm{K}$. The application of mepiquat chloride tended to significantly increase the oil refractive index, unsaponifiable matter and iodine value, while it tended to insignificantly decrease the oil acid value and saponification value, compared with the untreated control [37]. The application of plant growth regulators, particularly growth retardants may maintain internal hormonal balance, and efficient sink source relationship. This may be reflected in distinct changes in seed oil quality.

Saturated fatty acids in oil, lauric, myristic, palmitic and their total decreased, while capric and stearic increased by raising the N-rate (Table 17) [37]. The effect was significant only on palmitic acid, which was the dominant saturated fatty acid. A low content of saturated fatty acids is desirable for edible. The total unsaturated fatty acids (oleic and linoleic) and the ratio between total unsaturated fatty acids and total saturated fatty acids (TU/TS) were increased (by 2.42, and 10.69\%, respectively) by raising $\mathrm{N}$-rate (Table 18) [37]. The effect was significant only on oleic acid. Linoleic acid was the most

Table 16. Effect of $\mathrm{N}$ rate and foliar application of $\mathrm{K}$ and mepiquat chloride (MC) on seed oil properties ${ }^{\mathrm{a}}$.

\begin{tabular}{|c|c|c|c|c|c|}
\hline Treatments & Refractive index & Acid value & Saponification value & Unsaponifiable matter (\%) & Iodine value \\
\hline \multicolumn{6}{|l|}{$\mathrm{N}$ rate $\left(\mathrm{kg} \cdot \mathrm{ha}^{-1}\right)$} \\
\hline 95.2 & 1.4684 & 0.1339 & 190.8 & 0.3762 & 128.9 \\
\hline 142.8 & 1.4695 & 0.1313 & 189.7 & 0.3913 & 131.1 \\
\hline S.D. ${ }^{b}$ & 0.0011 & 0.0025 & 1.4 & 0.0178 & 3.3 \\
\hline \multicolumn{6}{|l|}{ K rate $\left(\mathrm{g} \cdot \mathrm{ha}^{-1}\right)$} \\
\hline 0 & 1.4682 & 0.1352 & 190.8 & 0.3675 & 125.8 \\
\hline 319 & 1.4689 & 0.1337 & 190.1 & 0.3825 & 130.3 \\
\hline 638 & 1.4692 & 0.1315 & 190.3 & 0.3875 & 131.6 \\
\hline 957 & 1.4694 & 0.1300 & 190.1 & 0.3975 & 132.4 \\
\hline S.D. ${ }^{b}$ & 0.0012 & 0.0021 & 1.5 & 0.0170 & 2.5 \\
\hline \multicolumn{6}{|l|}{ MC rate $\left(\mathrm{g} \cdot \mathrm{ha}^{-1}\right)$} \\
\hline 0 & 1.4683 & 0.1331 & 190.6 & 0.3750 & 128.3 \\
\hline $48+24$ & 1.4696 & 0.1321 & 189.9 & 0.3925 & 131.7 \\
\hline S.D. ${ }^{b}$ & 0.0011 & 0.0028 & 1.6 & 0.0172 & 3.0 \\
\hline
\end{tabular}

${ }^{\mathrm{a}}$ Mean data from a four replicate composites for the two seasons. ${ }^{\mathrm{b}}$ S.D. = standard deviation [37]. 
Table 17. Effect of $\mathrm{N}$ rate and foliar application of $\mathrm{K}$ and mepiquat chloride (MC) on the relative percentage of saturated fatty acids ${ }^{\mathrm{a}}$.

\begin{tabular}{|c|c|c|c|c|c|c|}
\hline \multirow{2}{*}{ Treatments } & \multicolumn{6}{|c|}{ Relative \% of saturated fatty acids } \\
\hline & Capric & Lauric & Myristic & Palmitic & Stearic & Total \\
\hline \multicolumn{7}{|l|}{$\mathrm{N}$ rate $\left(\mathrm{kg} \cdot \mathrm{ha}^{-1}\right)$} \\
\hline 95.2 & 0.068 & 0.068 & 0.691 & 21.77 & 2.157 & 24.753 \\
\hline 142.8 & 0.069 & 0.067 & 0.645 & 20.18 & 2.969 & 22.934 \\
\hline S.D. ${ }^{\mathrm{c}}$ & 0.009 & 0.006 & 0.451 & 1.44 & 0.470 & 2.283 \\
\hline \multicolumn{7}{|l|}{$\mathrm{K}$ rate $\left(\mathrm{g} \cdot \mathrm{ha}^{-1}\right)$} \\
\hline 0 & 0.077 & 0.074 & 1.307 & 22.40 & 2.602 & 26.467 \\
\hline 319 & 0.072 & 0.070 & 0.675 & 21.02 & 1.955 & 23.792 \\
\hline 638 & 0.065 & 0.063 & 0.350 & 20.52 & 1.905 & 22.903 \\
\hline 957 & 0.061 & 0.062 & 0.340 & 19.96 & 1.790 & 22.212 \\
\hline S.D. ${ }^{\mathrm{c}}$ & 0.006 & 0.004 & 0.180 & 1.47 & 0.369 & 1.925 \\
\hline \multicolumn{7}{|l|}{ MC rate $\left(\mathrm{g} \cdot \mathrm{ha}^{-1}\right)$} \\
\hline 0 & 0.074 & 0.065 & 0.775 & 21.97 & 2.336 & 25.221 \\
\hline $48+24$ & 0.064 & 0.069 & 0.561 & 19.98 & 1.790 & 22.465 \\
\hline S.D. ${ }^{c}$ & 0.007 & 0.006 & 0.437 & 1.29 & 0.382 & 1.998 \\
\hline
\end{tabular}

${ }^{\mathrm{a}}$ Mean data from a four replicate composite for the two seasons. ${ }^{\mathrm{b}} \mathrm{TU} / \mathrm{TS}$ ratio = (total unsaturated fatty acids)/(total saturated fatty acids). ${ }^{\mathrm{c}}$. $\mathrm{D}$. $=$ standard deviation [37].

Table 18. Effect of $\mathrm{N}$ rate and foliar application of $\mathrm{K}$ and mepiquat chloride (MC) on the relative percentage of unsaturated fatty acids ${ }^{\mathrm{a}}$.

\begin{tabular}{|c|c|c|c|c|}
\hline \multirow{2}{*}{ Treatments } & \multicolumn{3}{|c|}{ Relative $\%$ of unsaturated fatty acids } & \multirow{2}{*}{$\begin{array}{c}\mathrm{TU} / \mathrm{TS}^{\mathrm{b}} \\
\text { ratio }\end{array}$} \\
\hline & Oleic & Linoleic & Total & \\
\hline \multicolumn{5}{|l|}{$\mathrm{N}$ rate $\left(\mathrm{kg} \cdot \mathrm{ha}^{-1}\right)$} \\
\hline 95.2 & 21.59 & 53.65 & 75.24 & 3.069 \\
\hline 142.8 & 22.99 & 54.08 & 77.06 & 3.397 \\
\hline S.D. ${ }^{c}$ & 1.35 & 1.14 & 2.28 & 0.403 \\
\hline \multicolumn{5}{|l|}{$\mathrm{K}$ rate $\left(\mathrm{g} \cdot \mathrm{ha}^{-1}\right)$} \\
\hline 0 & 21.26 & 52.26 & 73.53 & 2.790 \\
\hline 319 & 22.11 & 54.10 & 76.20 & 3.228 \\
\hline 638 & 22.60 & 54.50 & 77.09 & 3.390 \\
\hline 957 & 23.18 & 54.60 & 77.78 & 3.523 \\
\hline S.D. ${ }^{c}$ & 1.37 & 0.63 & 1.92 & 0.351 \\
\hline \multicolumn{5}{|l|}{ MC rate $\left(\mathrm{g} \cdot \mathrm{ha}{ }^{-1}\right)$} \\
\hline 0 & 21.27 & 53.51 & 74.77 & 2.974 \\
\hline $48+24$ & 23.31 & 54.22 & 77.53 & 3.451 \\
\hline S.D. ${ }^{c}$ & 1.09 & 1.10 & 1.99 & 0.349 \\
\hline
\end{tabular}

${ }^{\mathrm{a}}$ Mean data from a four replicate composite for the two seasons. ${ }^{\mathrm{b}} \mathrm{TU} / \mathrm{TS}$ ratio $=$ (total unsaturated fatty acids)/(total saturated fatty acids). ${ }^{\mathrm{C}} \mathrm{S} . \mathrm{D} .=$ standard deviation [37].

abundant unsaturated fatty acid. Holmes and Bennett [104] commented that, the fatty acid composition of rape oil is mainly under genetic control, but can be modified to some extent by $\mathrm{N}$ nutrition. Seo et al. [105] found that, when sesame was given 0 to $160 \mathrm{~kg} \mathrm{~N}$, oleic acid content was highest at the highest $\mathrm{N}$ rates and linoleic acid content was highest at the intermediate rates. Khan et al. [88] indicated that, oleic acid increased by increasing levels of $\mathrm{N}$ added to rapeseed-mustard. Kheir et al. [7], in flax, found that the higher $\mathrm{N}$-rate increased the percentage of unsaturated fatty acids and decreased saturated fatty acids in the seed oil. Potassium applied at all concentrations resulted in a decrease in the total saturated fatty acids (capric, lauric, myristic, palmitic and stearic) com- 
pared with the untreated control (Table 17) [37]. Spraying plants with the high $\mathrm{K}$ concentration $957 \mathrm{~g} \cdot \mathrm{K} \cdot \mathrm{ha}^{-1}$ gave the lowest total saturated fatty acids oil, compared with the other two concentrations (638 and $957 \mathrm{~g} \cdot \mathrm{K} \cdot \mathrm{ha}^{-1}$ ). The effect was significant for the two concentrations 638 and $957 \mathrm{~g} \cdot \mathrm{K} \cdot \mathrm{ha}^{-1}$ on capric, and palmitic, and for all different concentrations on lauric, myristic, stearic, and the total saturated fatty acids. Potassium applied at all rates increased the total unsaturated fatty acid (oleic and linoleic) and TU/TS ratio (by 1.84 - 4.48, and $15.70 \%$ $26.27 \%$, respectively), compared with untreated control (Table 18) [37]. Applied $\mathrm{K}$ at $957 \mathrm{~g} \cdot \mathrm{ha}^{-1}$ gave the highest increment, followed by $638 \mathrm{~g} \cdot \mathrm{ha}^{-1}$ concentration. The effect was significant for all different concentrations on linoleic, the total unsaturated fatty acid and TU/TS ratio [37]. Linoleic acid was the most abundant unsaturated fatty acid. The beneficial effect of applied K on TU and TU/TS ratio suggests that it might be due to the regulated effect of $\mathrm{K}$ which acts as an activator on many enzymic processes, where some of these enzymes may affect the seed oil content from these organic matters. Seo et al. [105] found that, when sesame was given 0 to180 kg $\mathrm{K}_{2} \mathrm{O}$, oleic acid content was the highest at the highest $\mathrm{K}$ rates and linoleic acid content was the highest at the intermediate rates. Salama [106] indicated that, K fertilizer applied to sunflower, favored fatty acid composition (high oleic acid content). Mekki et al. [84] stated that, foliar application with $\mathrm{K}$ on sunflower increased the oleic acid fatty acid. Froment et al. [85] found that, linoleic acid content was greatest in linseed oil in treatments receiving extra $\mathrm{K}$. The application of MC resulted in a decrease in the total saturated fatty acids, the abundant saturated fatty acid palmitic, capric, myristic, and stearic, while it resulted in an increase in lauric saturated fatty acid, compared to the untreated control (Table 17) [37]. The effect was significant only on capric, palmitic, stearic and the total. The application of mepiquat chloride resulted in an increase in total unsaturated fatty acids (oleic and linoleic) and TU/TS ratio (by 3.69, and $16.69 \%$, respectively), over the control (Table 18). The effect was significant only on the total unsaturated fatty acid, oleic and TU/TS ratio [37]. The stimulatory residual effects of the application mepiquat chloride on TU and TU/TS ratio was probably due to its favorable effects on fundamental metabolic reactions in plant tissues, and would have direct impact through utilization on growth processes, which are reflected in distinct changes in seed oil quality [37]. Some of these changes may affect the seed oil fatty acids composition, which may attribute to their encouraging effects on enzymes that catalyzed the biosynthesis of unsaturated fatty acids. Mekki and El-Kholy [107] investigated the response of rape oilseed to 0,200 or 400 ppm mepiquat chloride and found that; palmitic acid was only decreased by using 400 ppm me- piquat chloride as compared with 200-ppm treatment or control plants. A low content of saturated fatty acids is desirable for edible purposes. Also, regarding oil quality, higher levels of linoleic acid and oleic acid are considered good for oil quality [108].

\section{CONCLUSIONS}

From the findings of this study, it seems rational to recommend application of $\mathrm{N}$ at a rate of $161 \mathrm{of} \mathrm{kg} \cdot \mathrm{ha}^{-1}$, spraying of cotton plants with plant PGR, and application of $\mathrm{Zn}$ in comparison with the ordinary cultural practices adopted by Egyptian cotton producers, as it is quite apparent that applications of such PGR, Zn, and increased $\mathrm{N}$ fertilization rates could bring about better impact on cottonseed yield, seed protein content, oil and protein yields, oil refractive index, unsaponifiable matter, and unsaturated fatty acids. On the other hand, there was a decrease in acid value and saponification value. The increase in seed yield and subsequent increase in oil and meal due to the application of PGR, Zn, and increased $\mathrm{N}$ fertilization were sufficient to cover the cost of using those chemicals and further attain an economical profit [35].

It can be concluded that addition of $\mathrm{P}$ at $74 \mathrm{~kg} \cdot \mathrm{ha}^{-1}$, and foliar application of $\mathrm{Zn}$ and $\mathrm{Ca}$ at different concentrations (especially Ca concentration of $60 \mathrm{ppm}$ ) beneficially affected cottonseed yield, seed index, seed oil content, oil and protein yields ha ${ }^{-1}$, seed oil unsaponifiable matter, and total unsaturated fatty acids (oleic and linoleic) [36].

The addition of $\mathrm{K}$ at $47.4 \mathrm{~kg} \cdot \mathrm{ha}^{-1}$, spraying cotton plants with Zn twice (at $57.6 \mathrm{~g} \cdot \mathrm{ha}^{-1}$ ), and also with $\mathrm{P}$ twice (especially the $\mathrm{P}$ concentration of $1728 \mathrm{~g} \cdot \mathrm{ha}^{-1}$ ) along with the soil fertilization used $\mathrm{P}$ at sowing time have been proven beneficial to the quality and yield of cotton plants. These combinations appeared to be the most effective treatments, affecting not only the quantity but also the quality of oil, and obtaining higher oil and protein yields and a better fatty acid profile in the oil of cotton. In comparison with the ordinary cultural practices adopted by Egyptian cotton producers, it is apparent that the applications of such treatments could produce an improvement in cottonseed yield, seed protein content, oil and protein yields, oil refractive index, unsaponifiable matter, iodine value, unsaturated fatty acids and a decrease in oil acid value and saponification value. The increase in seed yield and subsequent increase in oil and meal due to the addition of $\mathrm{K}$, spraying cotton plants with $\mathrm{Zn}$ and of $\mathrm{P}$ are believed to be sufficient enough to cover the cost of using those chemicals and obtain an economic profit at the same time [1].

Application of $\mathrm{N}$ at the rate of $143 \mathrm{~kg} \cdot \mathrm{ha}^{-1}$ and two applications of both $\mathrm{K}$ (foliar; at the rate of $957 \mathrm{~g} \cdot \mathrm{K} \cdot \mathrm{ha}^{-1}$ ) and mepiquat chloride (at a rate of $48+24 \mathrm{~g} \mathrm{a.i.} \mathrm{ha}^{-1}$, respectively) have the most beneficial effects among the 
treatments examined, affecting not only the seed quantity (to obtain higher oil and protein yields ha $^{-1}$ ) but also the oil seed quality (as indicated by better fatty acid profile in the oil of cotton) in comparison with the usual cultural practices adopted by Egyptian cotton procedures [37].

\section{REFERENCES}

[1] Sawan, Z.M., Hafez, S.A., Basyony, A.E. and Alkassas, A.R. (2007) Cottonseed: Protein, oil yields, and oil properties as influenced by potassium fertilization and foliar application of zinc and phosphorus. Grasas Y. Aceites, 58, 40-48.

[2] Reddy, A.R., Reddy, K.R., Padjung, R. and Hodges, H.F. (1996) Nitrogen nutrition and photosynthesis in leaves of Pima cotton. Journal of Plant Nutrition, 19, 755-770. http://dx.doi.org/10.1080/01904169609365158

[3] Rinehardt, J.M., Edmisten, K.L., Wells, R. and Faircloth, J.C. (2004) Response of ultra-narrow and conventional spaced cotton to variable nitrogen rates. Journal of Plant Nutrition, 27, 743-755. http://dx.doi.org/10.1081/PLN-120030379

[4] Ansari, M.S. and Mahey, R.K. (2003) Growth and yield of cotton species as affected by sowing dates and nitrogen levels. Punjab Agricultural University, Journal of Research, 40, 8-11.

[5] Patil, B.N., Lakkineni, K.C. and Bhargava, S.C. (1996) Seed yield and yield contributing characters as influenced by $\mathrm{N}$ supply in rapeseed-mustared. Journal of Agronomy and Crop Science, 177, 197-205. http://dx.doi.org/10.1111/j.1439-037X.1996.tb00237.x

[6] Frink, C.R., Waggoner, P.E. and Ausubel, J.H. (1999) Nitrogen fertilizer: Retrospect and prospect. Proceedings of the National Academy of Sciences of the United States of America, 96, 1175-1180.

http://dx.doi.org/10.1073/pnas.96.4.1175

[7] Kheir, N.F., Harb, E.Z., Moursi, H.A. and El-Gayar, S.H. (1991) Effect of salinity and fertilization on flax plants (Linum usitatissimum L.). II. Chemical composition. Bulletin of Faculty of Agriculture-University of Cairo, 42, 57-70.

[8] Taiz, L. and Zeiger, E. (1991) Plant physiology: Mineral nutrition. The Benjamin Cummings Publishing Co., Inc. Redwood City, 100-119.

[9] Rodriguez, D., Zubillaga, M.M., Ploschuck, E., Keltjens, W., Goudriaan, J. and Lavado, R. (1998) Leaf area expansion and assimilate prediction in sunflower growing under low phosphorus conditions. Plant and Soil, 202, 133147. http://dx.doi.org/10.1023/A:1004348702697

[10] Sasthri, G., Thiagarajan, C.P., Srimathi, P., Malarkodi, K. and Venkatasalam, E.P. (2001) Foliar application of nutrient on the seed yield and quality characters of nonaged and aged seeds of cotton cv. MCU5. Madras Agricultural Journal, 87, 202-206.

[11] Stewart, W.M., Reiter, J.S. and Krieg, D.R. (2005) Cotton response to multiple application of phosphorus fertilizer. Better Crops with Plant Food, 89, 18-20.

[12] Singh, V., Pallaghy, C.K. and Singh, D. (2006) Phospho- rus nutrition and tolerance of cotton to water stress: I. Seed cotton yield and leaf morphology. Field Crops Research, 96, 191-198. http://dx.doi.org/10.1016/j.fcr.2005.06.009

[13] Ibrahim, M.E., Bekheta, M.A., El-Moursi, A. and Gaafar, N.A. (2009) Effect of arginine, prohexadione-Ca, some macro and micro-nutrients on growth, yield and fiber quality of cotton plants. World Journal of Agricultural Sciences, 5, 863-870.

[14] Gebaly Sanaa, G. and El-Gabiery, A.E. (2012) Response of cotton Giza 86 to foliar application of phosphorus and mepiquat chloride under fertile soil condition. Journal of Agricultural Research, 90, 191-205.

[15] Sangakkara, U.R., Frehner, M. and Nösberger, J. (2000) Effect of soil moisture and potassium fertilizer on shoot water potential, photosynthesis and partitioning of carbon in mungbean and cowpea. Journal of Agronomy and Crop Science, 185, 201-207. http://dx.doi.org/10.1046/j.1439-037x.2000.00422.x

[16] Colomb, B., Bouniols, A. and Delpech, C. (1995) Effect of various phosphorus availabilities on radiation-use efficiency in sunflower biomass until anthesis. Journal of Plant Nutrition, 18, 1649-1658. http://dx.doi.org/10.1080/01904169509365010

[17] Gormus, O. (2002) Effects of rate and time of potassium application on cotton yield and quality in Turkey. Journal of Agronomy and Crop Science, 188, 382-388. http://dx.doi.org/10.1046/j.1439-037X.2002.00583.x

[18] Aneela, S., Muhammad, A. and Akhtar, M.E. (2003) Effect of potash on boll characteristics and seed cotton yield in newly developed highly resistant cotton varieties. $\mathrm{Pa}$ kistan Journal of Biological Sciences, 6, 813-815.

[19] Pervez, H., Ashraf, M. and Makhdum, M.I. (2004) Influence of potassium rates and sources on seed cotton yield and yield components of some elite cotton cultivars. Journal of Plant Nutrition, 27, 1295-1317. http://dx.doi.org/10.1081/PLN-120038549

[20] Pettigrew, W.T., Meredith Jr., W.R. and Young, L.D. (2005) Potassium fertilization effects on cotton lint yield, yield components, and reniform nematode populations. Agronomy Journal, 97, 1245-1251. http://dx.doi.org/10.2134/agronj2004.0321

[21] Sharma, S.K. and Sundar, S. (2007) Yield, yield attributes and quality of cotton as influenced by foliar application of potassium. Journal of Cotton Research and Development, 21, 51-54.

[22] Welch, R.M. (1995) Micronutrient nutrition of plants. Critical Reviews in Plant Sciences, 14, 49-82.

[23] Oosterhuis, D., Hake, K. and Burmester, C. (1991) Leaf feeding insects and mites. Cotton council of America. Cotton Physiology Today, 2, 1-7.

[24] Rathinavel, K., Dharmalingam, C. and Paneersel vam, S. (2000) Effect of micronutrient on the productivity and quality of cotton seed cv. TCB 209 (Gossypium barbadense L.). Madras Agricultural Journal, 86, 313-316.

[25] Li, L.L., Ma, Z.B., Wang, W.L. and Tai, G.Q. (2004) Effect of spraying nitrogen and zinc at seedling stage on some physiological characteristics and yield of summer cotton. Journal of Henan Agricultural University, 38, 33-35. 
[26] Rensing, L. and Cornelius, G. (1980) Biological membranes as components of oscillating systems. Biologische Rundschau, 18, 197-209.

[27] Ma, L.G. and Sun, D.Y. (1997) The involvement of calcium in the light signal transduction chain for phototropism in sunflower seedling. Biologia Plantarum, 39, 569-574.

[28] Ochiai, E.L. (1977) Bioinorganic chemistry. Allyn \& Bacon, Boston, 515 p.

[29] Zhao, D.L. and Oosterhuis, D.M. (2000) Pix plus and mepiquat chloride effects on physiology, growth, and yield of field-grown cotton. Journal of Plant Growth Regulation, 19, 415-422.

[30] Wang, Z.L., Yin, Y.P. and Sun, X.Z. (1995) The effect of DPC (N, N-dimethyl piperidinium chloride) on the ${ }^{14} \mathrm{CO}_{2^{-}}$ assimilation and partitioning of ${ }^{14} \mathrm{C}$ assimilates within the cotton plants interplanted in a wheat stand. Photosynthetica, 31, 197-202.

[31] Kumar, K.A.K., Patil, B.C. and Chetti, M.B. (2004) Effect of plant growth regulators on biophysical, biochemical parameters and yield of hybrid cotton. Karnataka Journal of Agricultural Sciences, 16, 591-594.

[32] Palomo Gil, A. and Chávez González, J.F. (1997) Response of the early cotton cultivar CIAN 95 to nitrogen fertilizer application. ITEA. Producción Vegetal, 93, 126132.

[33] Sarwar Cheema, M., Akhtar, M. and Nasarullah, M. (2009) Effect of foliar application of mepiquat chloride under varying nitrogen levels on seed cotton yield and yield components. Journal of Agricultural Research, 47, 381-388.

[34] Patil, D.B., Naphade, K.T., Wankhade, S.G., Wanjari, S.S. and Potdukhe, N.R. (1997) Effect of nitrogen and phosphate levels on seed protein and carbohydrate content of cotton cultivars. Indian Journal of Agricultural Research, 31, 133-135.

[35] Sawan, Z.M., Hafez, S.A. and Basyony, A.E. (2001) Effect of nitrogen and zinc fertilization and plant growth retardants on cottonseed, protein, oil yields, and oil properties. Journal of the American Oil Chemists' Society, 78, 1087-1092.

[36] Sawan, Z.M., Hafez, S.A. and Basyony, A.E. (2001) Effect of phosphorus fertilization and foliar application of chelated zinc and calcium on seed, protein and oil yields and oil properties of cotton. Journal of Agricultural Science, 136, 191-198.

[37] Sawan, Z.M., Hafez, S.A., Basyony, A.E. and Alkassas, A.R. (2007) Nitrogen, potassium and plant growth retardant effects on oil content and quality of cotton seed. Grasas Y. Aceites, 58, 243-251.

[38] Sawan, Z.M., Fahmy, A.H. and Yousef, S.E. (2009) Direct and residual effects of nitrogen fertilization, foliar application of potassium and plant growth retardant on Egyptian cotton growth, seed yield, seed viability and seedling vigor. Acta Ecologica Sinica, 29, 116-123. http://dx.doi.org/10.1016/j.chnaes.2009.05.008

[39] Association of Official Analytical Chemists (1985) Official methods of analysis. 14th Edition, Association of Analytical Communities (AOAC), Arlington.

[40] Kates, M. (1972) Laboratory techniques in biochemistry and molecular biology. In: Work, T.S. and Work, E., Eds., North-Holland Publishing, Amsterdam.

[41] American Oil Chemists' Society (1985) Official methods and recommended practices of the american oil chemists' society. In: Walker, R.O., Ed., 3rd Edition, American Oil Chemists' Society, Champaign.

[42] Vogel, A.I. (1975) A textbook of practical organic chemistry. 3rd Edition, English Language Book Society and Longman Group, Harlow.

[43] Ashoub, A.H., Basyony, A.E. and Ebad, F.A. (1989) Effect of plant population and nitrogen levels on rapeseed oil quality and quantity. Annals of Agricultural Science, Moshtohor, 27, 761-770.

[44] Snedecor, G.W. and Cochran, W.G. (1980) Statistical methods. 7th Edition, Iowa State University Press, Ames.

[45] Abdel-Malak, K.I., Radwan, F.E. and Baslious, S.I. (1997) Effect of row width, hill spacing and nitrogen levels on seed cotton yield of Giza 83 cotton cultivar. Egyptian Journal of Agricultural Research, 75, 743-752.

[46] Saleem, M.F., Shakeel, A., Bilal, M.F., Shahid, M.Q. and Anjum, S.A. (2010) Effect of different phosphorus levels on earliness and yield of cotton cultivars. Soil \& Environment, 29, 128-135.

[47] Hamed, F.S., Abo El-Hamd, A.S., Ibrahim, M.M. and ElSayed, A.E.M. (2012) Effect of some cultural practices on growth, flowering, earliness characters and yield of cotton plant variety Giza 90 (Gossypium barbadense L.). Egyptian Journal of Agricultural Research, 90, 1649-1673.

[48] Gardner, F.P. (1988) Growth and partitioning in peanut as influenced by gibberellic acid and daminozide. Agronomy Journal, 80, 159-163.

http://dx.doi.org/10.2134/agronj1988.0002196200800002 $\underline{0004 x}$

[49] Nepomuceno, A.L., Oosterhuis, D.M. and Steger, A. (1997) Duration of activity of the plant growth regulators PGR-IV and mepiquat chloride. Special Reports-Agricultural Experiment Station, Division of Agriculture, University of Arkansas, Arkansas, No. 183, 136-139.

[50] Abdel-Al, M.H. (1998) Response of Giza 85 cotton cultivar to the growth regulators Pix and Atonic. Egyptian Journal of Agricultural Research, 76, 1173-1181.

[51] Pípolo, A.E., Athayde, M.L.F., Pípolo, V.C. and Parducci, S. (1993) Comparison of different rates of chlorocholine chloride applied to herbaceous cotton. Pesquisa Agropecuária Brasileira, 28, 915-923.

[52] Sawan, Z.M., Basyony, A.E., McCuistion, W.L. and ElFarra, A.A. (1993) Effect of plant population densities and application of growth retardants on cottonseed yield and quality. Journal of the American Oil Chemists' Society, 70, 313-317.

[53] Zeng, Q.F. (1996) Researchers on the effect of zinc applied to calcareous soil in cotton field. China Cottons, 23, 21.

[54] Carvalho, L.H., Chiavegato, E.J., Cia, E., Kndo, J.I., Sabino, J.C., Pettinelli Junior, A., Bortoletto, N. and Gallo, P.B. (1994) Plant growth regulators and pruning in the cotton crop. Bragantia, 53, 247-254. http://dx.doi.org/10.1590/S0006-87051994000200014

[55] Pandrangi, R.B., Wankhade, S.G. and Kedar, G.S. (1992) 
Response of cotton (Gossypium hirsutum L.) to N and P grown under rainfed conditions. Crop Research, 5, 54-58.

[56] Sawan, Z.M., Sakr, R.A., Ahmed, F.A. and Abd-Al-Samad, A.M. (1991) Effect of 1,1-dimethyl piperidinium chloride (Pix) on the seed, protein, oil and fatty acids of Egyptian cotton. Journal of Agronomy and Crop Science, 166, 157161. http://dx.doi.org/10.1111/j.1439-037X.1991.tb00899.x

[57] Sawan, Z.M., El-Farra, A.A. and Mohamed, Z.A. (1988) Effect of nitrogen fertilization, foliar application of calcium and some micro-elements on cottonseed, protein and oil yields and oil properties of Egyptian cotton. Annali di Botanica, 46, 167-174.

[58] Prabhuraj, D.K., Badiger, M.K. and Manure, G.R. (1993) Growth and yield of sunflower (Helianthus annuus) as influenced by levels of phosphorus, sulphur and zinc. Indian Journal of Agronomy, 38, 427-430.

[59] Bybordi, A. and Mamedov, G. (2010) Evaluation of application methods efficiency of zinc and iron for canola (Brassica napus L.). Notula Scientia Biologicae, 2, 94103.

[60] Sugiyama, T., Mizuno, M. and Hayashi, M. (1984) Partitioning of nitrogen among Ribulose-1, 5-bisphosphate carboxylase/oxygenase, phosphoenolpyruvat carboxylase, and pyruvate orthophosphate dikinase as related to biomass productivity in maize seedlings. Plant Physiology, 75, 665-669. http://dx.doi.org/10.1104/pp.75.3.665

[61] Hedin, P.A., McCarthy, J.C. and Jenkins, J.N. (1988) Effect of CCC and PIX related bioregulators on gossypol, protein, yield and seed properties of cotton. Journal of the Mississippi Academy of Sciences, 33, 49-57.

[62] Kar, C., Barua, B. and Gupta, K. (1989) Response of the safflower plant (Carthamus tinctorius L. cV. JLA 900) towards plant growth retardants dikegulac sodium, CCC and SADH. Indian Journal of Plant Physiology, 23, 144147.

[63] Wang, H.Y. and Chen, Y. (1984) A study with ${ }^{32} \mathrm{P}$ on the effect of growth regulators on the distribution of nutrients with cotton plants. China Cottons, 4, 29-30.

[64] Kler, D.S., Raj, D. and Dhillon, G.S. (1991) Chemical regulated growth, development and light penetration in American cotton (Gossypium hirsutum L.). Environment and Ecology, 9, 584-588.

[65] Osman, R.O. and Abu-Lila, B.H. (1985) Studies on the effect of gibberellic acid and Cycocel on flax plants ( $\mathrm{Li}$ num usitatissimum L.), seed oil content and oil composition. Zeitschrift für Acker-und Pflanzenbau, 155, 82-88.

[66] Guinn, G. (1984) Boll abscission in cotton. In: Gupta, U.S., Ed., Crop Physiology: Advancing Frontiers, Mohan Primlani for Oxford \& IBH Publishing Co., New Delhi, 177-225.

[67] Saleem, M.F., Shakeel, A., Bilal, M.F., Shahid, M.Q. and Anjum, S.A. (2010) Effect of different phosphorus levels on earliness and yield of cotton cultivars. Soil \& Environment, 29, 128-135.

[68] Glass, A.D.M. (1989) Plant nutrition. An introduction to current concepts. Jones and Bartlett Publishers, Boston/ Portola Valley.
[69] Shui, J.G. and Meng, S.F. (1990) Effects of lime application on cotton yield in red soil fields. China Cottons, 1, 26-29.

[70] Wright, S.D., Munk, D., Munier, D., Vargas, R., Weir, B., Roberts, B. and Jimenez Jr., M. (1995) Effect of aminofol/ boll-set plus calcium zinc on California cotton. Proceedings Beltwide Cotton Conferences, San Antonio, TX, USA, 4-7 January 1995, Volume 2, National Cotton Council, Memphis.

[71] Kosheleva, L.L., Bakhnova, K.V., Semenova, T.A. and Mil'Kevich, Z.A. (1984) Effect of phosphorus nutrition on metabolism of young fiber flax plants in relation to assimilate distribution in them. Referativnyi Zhurnal, 6, 533.

[72] El-Debaby, A.S., Hammam, G.Y. and Nagib, M.A. (1995) Effect of planting date, $\mathrm{N}$ and $\mathrm{P}$ application levels on seed index, lint percentage and technological characters of Giza 80 cotton cultivar. Annals of Agricultural Science, Moshtohor, 33, 455-464.

[73] Bora, P.C. (1997) Effect of gypsum and lime on performance of Brassica varieties under rainfed condition. Indian Journal of Agronomy, 42, 155-158.

[74] Davidson, F.M. and Long, C.M. (1958) The structure of the naturally occurring phosphoglycerides. 4. Action of cabbage leaf phospholipase. Biochemical Journal, 69, 458.

[75] Shchitaeva, V.A. (1984) Effect of zinc on metabolic activity of the root system of fine-fibered cotton. Izvestiya Akademii Nauk Turkmenskoi SSR, Biologicheskaya, 4, 8-13.

[76] Gushevilov, Zh. and Palaveeva, Ts. (1991) Effect of longterm systematic fertilizer application on sunflower yield and quality. Pochvoznanie i Agrokhimiya, 26, 20-26.

[77] Gebaly Sanaa, G. (2012) Physiological effects of potassium forms and methods of application on cotton variety Giza 80. Egyptian Journal of Agricultural Research, 90, 1633-1646.

[78] Russell, E.W. (1973) Soil condition and plant growth. The English Language Book Society and Longman, London, $448 \mathrm{p}$.

[79] Ghourab, M.H.H., Wassel, O.M.M. and Raya, N.A.A. (2000) Response of cotton plants to foliar application of (Pottasin-P) ${ }^{\mathrm{TM}}$ under two levels of nitrogen fertilizer. Egyptian Journal of Agricultural Research, 78, 781-793.

[80] Wiatrak, P.J., Wright, D.L. and Marois, J.J. (2006) Development and yields of cotton under two tillage systems and nitrogen application following white lupine grain crop. Journal of Cotton Science, 10, 1-8.

[81] Cakmak, I. (2000) Possible roles of zinc in protecting plant cells from damage by reactive oxygen species. New Phytologist, 146, 185-205. http://dx.doi.org/10.1046/j.1469-8137.2000.00630.x

[82] Bednarz, C.W. and Oosterhuis, D.M. (1999) Physiological changes associated with potassium deficiency in cotton. Journal of Plant Nutrition, 22, 303-313. http://dx.doi.org/10.1080/01904169909365628

[83] Marschner, H. (1995) Mineral nutrition of higher plants. 2nd Edition, Academic Press, London.

[84] Mekki, B.B., El-Kholy, M.A. and Mohamed, E.M. (1999) Yield, oil and fatty acids content as affected by water deficit and potassium fertilization in two sunflower culti- 
vars. Egyptian Journal of Agronomy, 21, 67-85.

[85] Froment, M.A., Turley, D. and Collings, L.V. (2000) Effect of nutrition on growth and oil quality in linseed. Tests of Agrochemicals and Cultivars, 21, 29-30.

[86] Klug, A. and Rhodes, D. (1987) "Zinc fingers": A novel protein motif for nucleic acid recognition. Trends in Biochemical Sciences, 12, 464-469. http://dx.doi.org/10.1016/0968-0004(87)90231-3

[87] Romheld, V. and Marschner, H. (1991) Micronutrients in agriculture. 2nd Edition, Soil Science Society of America Book Series, no 4, Soil Science Society of America, Inc., Madison, Wisconsin, 297-328.

[88] Khan, N.A., Ansari, H.R. and Samiullah (1997) Effect of gibberellic acid spray and Basal nitrogen and phosphorus on productivity and fatty acid composition of rapeseedmustard. Journal of Agronomy and Crop Science, 179, 2933. http://dx.doi.org/10.1111/j.1439-037X.1997.tb01144.x

[89] Legé, K.E., Cothren, J.T. and Morgan, P.W. (1997) Nitrogen fertility and leaf age effects on ethylene production of cotton in a controlled environment. Plant Growth Regulation, 22, 23-28.

[90] McConnell, J.S. and Mozaffari, M. (2004) Yield, petiole nitrate, and node development responses of cotton to early season nitrogen fertilization. Journal of Plant Nutrition, 27, 1183-1197. http://dx.doi.org/10.1081/PLN-120038543

[91] Pettigrew, W.T. (1999) Potassium deficiency increases specific leaf weights of leaf glucose levels in field-grown cotton. Agronomy Journal, 91, 962-968. http://dx.doi.org/10.2134/agronj1999.916962x

[92] Cakmak, I., Hengeler, C. and Marschner, H. (1994) Partitioning of shoot and root dry matter and carbohydrates in bean plants suffering from phosphorus, potassium and magnesium deficiency. Journal of Experimental Botany, 45, 1245-1250. http://dx.doi.org/10.1093/jxb/45.9.1245

[93] Mullins, G.L., Schwab, G.J. and Burmester, C.H. (1999) Cotton response to surface applications of potassium fertilizer: A 10-year summary. Journal of Production Agriculture, 12, 434-440.

http://dx.doi.org/10.2134/jpa1999.0434

[94] Prakash, R., Prasad, M. and Pachauri, D.K. (2001) Effect of nitrogen, chlormequat chloride and FYM on growth yield and quality of cotton (Gossypium hirsutum L.). Annals of Agricultural Research, 22, 107-110.

[95] Mekki, B.B. (1999) Effect of mepiquat chloride on growth, yield and fiber properties of some Egyptian cotton cultivars. Arab University Journal of Agricultural Science, 7, 455-466.

[96] Palomo Gil, A., Godoy Avila, S. and Chávez González,
J.F. (1999) Reductions in nitrogen fertilizers use with new cotton cultivars: Yield, yield components and fiber quality. Agrociencia, 33, 451-455.

[97] Ali, S.A. and El-Sayed, A.E. (2001) Effect of sowing dates and nitrogen levels on growth, earliness and yield of Egyptian cotton cultivar Giza 88. Egyptian Journal of Agricultural Research, 79, 221-232.

[98] Lamas, F.M. (2001) Comparative study of mepiquat chloride and chlormequat chloride application in cotton. Pesquisa Agropecuária Brasileira, 36, 265-272. http://dx.doi.org/10.1590/S0100-204X2001000200008

[99] Zubillaga, M.M., Aristi, J.P. and Lavado, R.S. (2002) Effect of phosphorus and nitrogen fertilization on sunflower (Helianthus annus L) nitrogen uptake and yield. Journal of Agronomy and Crop Science, 188, 267-274. http://dx.doi.org/10.1046/j.1439-037X.2002.00570.x

[100] Madraimov, I. (1984) Potassium fertilizers and oil content of cotton seeds. Khlopkovodstvo, 6, 11-12.

[101] Fan, S.L., Xu, Y.Z. and Zhang, C.J. (1999) Effects of nitrogen, phosphorus and potassium on the development of cotton bolls in summer. Acta Gossypii Sinica, 11, 24-30.

[102] Stitt, M. (1999) Nitrate regulation of metabolism and growth. Current Opinion in Plant Biology, 2, 178-186. http://dx.doi.org/10.1016/S1369-5266(99)80033-8

[103] Narang, R.S., Mahal, S.S. and Gill, M.S. (1993) Effect of phosphorus and sulphur on growth and yield of toria (Brassica campestris subsp. oleifera var toria). Indian Journal of Agronomy, 38, 593-597.

[104] Holmes, M.R.J. and Bennett, D. (1979) Effect of nitrogen fertilizer on the fatty acid composition of oil from low erucic acid rape varieties. Journal of the Science of Food and Agriculture, 30, 264-266. http://dx.doi.org/10.1002/jsfa.2740300309

[105] Seo, G.S., Jo, J.S. and Choi C.Y. (1986) The effect of fertilization level on the growth and oil quality in sesame (Sesamum indicum L.). Korean Journal of Crop Science, 31, 24-29.

[106] Salama, A.M. (1987) Yield and oil quality of sunflowers as affected by fertilizers and growth regulators. Növénytermelés, 36, 191-202.

[107] Mekki, B.B. and El-Kholy, M.A. (1999) Response of yield, oil and fatty acid contents in some oil seed rape varieties to mepiquat chloride. Bulletin of the National Research Center, 24, 287-299.

[108] Downey, R.K. and Rimmer, S.R. (1993) Agronomic improvement in oil seed Brassicas. Advances in Agronomy, 50, 1-66. http://dx.doi.org/101016/S0065-2113(08)60831-7

\section{ABBREVIATIONS}

Ca: calcium

$\mathrm{N}$ : nitrogen

P: phosphorus
PGRs: plant growth retardants

$\mathrm{K}$ : potassium

Zn: zinc 